\title{
Joint Cardioprotective Effect of Vitamin C and Other Antioxidants against Reperfusion Injury in Patients with Acute Myocardial Infarction Undergoing Percutaneous Coronary Intervention
}

\author{
Ramón Rodrigo ${ }^{1, *(D)}$, Juan Carlos Prieto ${ }^{1,2}$, Rubén Aguayo ${ }^{3}$, Cristóbal Ramos ${ }^{2}$, Ángel Puentes ${ }^{3}$, \\ Abraham Gajardo $^{2}$, Emiliano Panieri ${ }^{4}$ (D) Catalina Rojas-Solé ${ }^{1} \mathbb{D}$, José Lillo-Moya ${ }^{1}$ and Luciano Saso ${ }^{4}$ (D) \\ 1 Molecular and Clinical Pharmacology Program, Faculty of Medicine, Campus Norte, \\ Institute of Biomedical Sciences, University of Chile, Avda. Independencia 1027, Santiago 8380000, Chile; \\ jprieto@u.uchile.cl (J.C.P.); catalinarojass@ug.uchile.cl (C.R.-S.); joselillo@ug.uchile.cl (J.L.-M.) \\ 2 University of Chile Clinical Hospital, Campus Norte, Carlos Lorca Tobar 999, Independencia, Santiago \\ 8380456, Chile; cramos@u.uchile.cl (C.R.); abrahamgajardo@hotmail.com (A.G.) \\ 3 Cardiology Unit, Department of Medicine, Occident Division, San Juan de Dios Hospital, \\ Avenida Portales 3239, Santiago 8500000, Chile; raguayo@minsal.cl (R.A.); apuentescdt@yahoo.com (Á.P.) \\ check for \\ updates \\ 4 Department of Physiology and Pharmacology "Vittorio Erspamer", Faculty of Pharmacy and Medicine, \\ Sapienza University, P.le Aldo Moro 5, 00185 Rome, Italy; emiliano.panieri@isprambiente.it (E.P.); \\ luciano.saso@uniroma1.it (L.S.) \\ * Correspondence: rrodrigo@med.uchile.cl
}

Citation: Rodrigo, R.; Prieto, J.C.; Aguayo, R.; Ramos, C.; Puentes, Á.; Gajardo, A.; Panieri, E.; Rojas-Solé, C.; Lillo-Moya, J.; Saso, L. Joint Cardioprotective Effect of Vitamin C and Other Antioxidants against Reperfusion Injury in Patients with Acute Myocardial Infarction Undergoing Percutaneous Coronary Intervention. Molecules 2021, 26, 5702. https://doi.org/10.3390/ molecules 26185702

Academic Editor: Béla Juhász

Received: 25 August 2021

Accepted: 17 September 2021

Published: 21 September 2021

Publisher's Note: MDPI stays neutral with regard to jurisdictional claims in published maps and institutional affiliations.

Copyright: (c) 2021 by the authors. Licensee MDPI, Basel, Switzerland. This article is an open access article distributed under the terms and conditions of the Creative Commons Attribution (CC BY) license (https:// creativecommons.org/licenses/by/ $4.0 /)$.

\begin{abstract}
Percutaneous coronary intervention (PCI) has long remained the gold standard therapy to restore coronary blood flow after acute myocardial infarction (AMI). However, this procedure leads to the development of increased production of reactive oxygen species (ROS) that can exacerbate the damage caused by AMI, particularly during the reperfusion phase. Numerous attempts based on antioxidant treatments, aimed to reduce the oxidative injury of cardiac tissue, have failed in achieving an effective therapy for these patients. Among these studies, results derived from the use of vitamin $\mathrm{C}$ (Vit C) have been inconclusive so far, likely due to suboptimal study designs, misinterpretations, and the erroneous conclusions of clinical trials. Nevertheless, recent clinical trials have shown that the intravenous infusion of Vit C prior to PCI-reduced cardiac injury biomarkers, as well as inflammatory biomarkers and ROS production. In addition, improvements of functional parameters, such as left ventricular ejection fraction (LVEF) and telediastolic left ventricular volume, showed a trend but had an inconclusive association with Vit $C$. Therefore, it seems reasonable that these beneficial effects could be further enhanced by the association with other antioxidant agents. Indeed, the complexity and the multifactorial nature of the mechanism of injury occurring in AMI demands multitarget agents to reach an enhancement of the expected cardioprotection, a paradigm needing to be demonstrated. The present review provides data supporting the view that an intravenous infusion containing combined safe antioxidants could be a suitable strategy to reduce cardiac injury, thus improving the clinical outcome, life quality, and life expectancy of patients subjected to PCI following AMI.
\end{abstract}

Keywords: vitamin C; antioxidants; cardioprotection; ischemia-reperfusion; percutaneous coronary intervention

\section{Introduction}

During the last two decades, heart disease has remained the leading cause of death worldwide, accounting for $16 \%$ of deaths from all causes [1]. In this line, heart attacks and strokes account for up to four out of five deaths [2]. Acute myocardial infarction (AMI) occurs through the complete or partial lumen occlusion of a branch of coronary 
circulation. Atheroma plaques are vulnerable to rupture or erosion, thereby causing thrombotic alterations that result in blocking blood flow to the myocardial tissue [3]. Percutaneous coronary intervention (PCI) is an invasive non-surgical therapeutic procedure whose aim is to improve the blood supply directed to the ischemic tissue. For this purpose, the most common method is the inflation of the narrow segment or the deployment of a stent to keep the artery open and regain its volume [4]. At present, PCI remains the gold standard therapy for treating blood occlusion, particularly in AMI. Several trials have shown that PCI is more effective than thrombolytic therapy to restore blood flow in patients with ST-segment elevation myocardial infarction [5]. However, paradoxically, the restoration of blood flow in the ischemic myocardium also induces additional injury. This phenomenon was therefore termed myocardial ischemia reperfusion injury (MIRI). Subsequent studies in animal models of AMI have suggested that myocardial reperfusion accounts for up to $50 \%$ of the final size of a myocardial infarct [6]. The key role of oxidative stress in the pathophysiology of MIRI is due to the burst of reactive oxygen species (ROS) occurring immediately after the onset of reperfusion. In order to abrogate this injurious mechanism, numerous antioxidant treatments have aimed to reduce MIRI by enhancing the antioxidant defense system through the administration of vitamin $C$ (Vit C), vitamin $\mathrm{E}$ (Vit E), N-acetylcysteine (NAC), deferoxamine (DFO), and polyphenols, among others. However, these therapies have led to suboptimal results in animal models and have not produced consistent effects when tested in clinical trials. Consequently, to date, there has been no available therapy against MIRI for these patients, and it remains a challenge to develop an effective therapy.

Vit $C$ is involved in numerous physiological processes, and is known to exert pleiotropic therapeutic effects in a variety of human pathologies, including cardiovascular diseases [7]. Accordingly, it has been used to reduce oxidative stress in ischemia/reperfusion (I/R) processes, both in animal models and clinical trials, but its benefit in reducing MIRI remains uncertain. The lack of fundamental knowledge about the pharmacological properties of Vit $C$ has led to suboptimal design, misinterpretations, and the erroneous conclusions of clinical trials [8]. All of this has disallowed the drawing of definitive conclusions supporting a therapeutic use for Vit C. Nevertheless, there are some studies showing beneficial effects. Thus, Khan et al. [9] carried out a systematic review of randomized controlled trials including 1185 patients selected from 371 publications reporting cardioprotective effects of Vit $C$ during angioplasty, but also showing mixed results among the different studies. The administration of Vit $C$ prior to PCI reduced cardiac injury biomarkers, as well as inflammatory markers and ROS formation. However, despite improvements of functional parameters, such as the trend shown by left ventricular (LV) ejection fraction (LVEF) and the telediastolic left ventricular volume, the association with Vit $C$ was inconclusive. This could be due to an approach that points primarily towards the ROS scavenger ability of Vit $C$, rather than its mechanistic effects, such as its pharmacokinetics, pharmacodynamics, interaction with metal ions and their recycling. Moreover, AMI has a multifactorial nature, causing the death of cardiomyocytes and other heart tissue cell types through different pathways, such as apoptosis, necrosis, autophagy, and ferroptosis [10]. Accordingly, it has been previously proposed that cardioprotection for MIRI requires a synergistic or additive multitarget therapy [11]. This study provides data supporting the suitable use of an intravenous infusion containing combined safe antioxidants to reduce reperfusion cardiac injury. This enhanced cardioprotective effect might improve the clinical outcome, life quality, and life expectancy of AMI patients undergoing PCI.

\section{Ischemia-Reperfusion Induced Cardiac Injury and Oxidative Stress}

\subsection{Oxidative Stress Development}

Oxidative stress occurs due to an imbalance between the production of oxidant species and the activity of the antioxidant system, in favor of the first, which has been involved in the pathophysiological mechanisms of various cardiovascular pathologies [12]. Indeed, various reactive species are generated within the cells, either by enzymatic or non-enzymatic 
pathways, fulfilling an important physiological role in the regulation of important cellular functions through redox signaling. Thus, the physiological role of these species depends on their concentration at the steady state, the specific site, and the extent of their generation over time. According to their chemical nature, we can distinguish reactive oxygen species derived from oxygen, nitrogen, or sulfur, with the first two types being particularly relevant for human pathology. Reactive oxygen species include superoxide anion radical $\left(\mathrm{O}_{2} \cdot{ }^{-}\right)$, hydrogen peroxide $\left(\mathrm{H}_{2} \mathrm{O}_{2}\right)$, hydroxyl radical $(\cdot \mathrm{OH})$, and oxygen singlet $\left({ }^{1} \mathrm{O}_{2}\right)$. In turn, reactive nitrogen species are nitric oxide radical $(\mathrm{NO} \cdot)$, peroxynitrite anion $\left(\mathrm{ONOO}^{-}\right)$, and nitrogen dioxide radical (NOO). The main sources of ROS are physically located within the mitochondria, wherein physiological or even pathological amounts are generated by the electron transport chain complexes due the incomplete reduction of molecular oxygen, or by the metabolic enzymes of the Krebs cycle, with the 2-oxoglutarate dehydrogenase complex being the one with the highest production rates [13]. Other relevant enzymatic sources with cell-type and compartment-specific localization include reduced nicotinamide adenine dinucleotide phosphate (NADPH) oxidase (NOX), xanthine oxidase (XO), uncoupled endothelial nitric oxide synthase (un-eNOS), lipoxygenase/cyclo-oxygenases, and myeloperoxidase (MPO), among others [14]. In addition, ROS can be formed through nonenzymatic pathways, such as chemical redox reactions involving ferrous iron, hydrogen peroxide, and the superoxide anion (Fenton and Haber-Weiss reactions) leading to the production of $\mathrm{OH}$, the most reactive and harmful one. Increased ROS concentrations at the steady state can potentially cause damage to biomolecules, such as lipids, proteins, and DNA, thus altering their structure and normal functioning. The pathophysiological effects of this damage range from an inflammatory state to several forms of cell death [15].

\subsection{Antioxidant Defense System}

In order to comply with the oxidative challenges, the cell has evolved a wide array of mechanisms that collectively constitute the antioxidant system. Its main function is to constantly shape the steady-state levels of ROS production to either support redox signaling events or to counteract the uncontrolled elevation of ROS levels, thus preventing or repairing the oxidative damage. This defense system works through both enzymes and other non-enzymatic molecules, being superoxide dismutases (SODs), catalase (CAT), peroxiredoxins (PRXs), thioredoxins (TRXs), glutaredoxins (GRXs), and glutathione peroxidases (GPXs), the main enzymes and the first line of defense against oxidative damage [14] On the other hand, non-enzymatic antioxidant molecules are represented by endogenous components, such as reduced glutathione (GSH), NADPH, and exogenous molecules including Vit C, Vit E, carotenoids, flavonoids, and polyphenols, among others [14,16]. It is of interest to mention that the antioxidant enzymatic response is largely mediated by the nuclear factor-erythroid 2-related factor 2 (Nrf2) pathway, wherein the exposure to various oxidants induces the dissociation of the inhibitory Kelch-like ECH-associated protein 1 (Keap1) subunit from the Nrf2 protein, allowing the latter to be translocated into the nucleus. Here, Nrf2 binds to the site of antioxidant response elements (AREs), stimulating the transcription of genes that code for antioxidant enzymes, such as CAT, GPX, heme oxygenase-1 (HO-1), glutathione synthase (Gclc and Gclm), and glutathione reductase (GR), thereby contributing to the maintenance of the cellular redox balance $[17,18]$. The relevance of this pathway in cardioprotection has been suggested by studies reporting that Nrf2 knockout mice have a larger infarct size in response to regional ischemia/reperfusion events, which was decreased by ischemic preconditioning strategies [19]. In addition, Zhang et al. [20] reported that the use of preconditioning strategies induces cardioprotection through the Nrf2 pathway, increasing the enzymatic antioxidant response and the GSH/GSSG index in rabbit hearts subjected to MIRI.

As mentioned previously, ROS can have physiological or harmful functions depending on their concentration and temporal generation. In low or moderate concentrations they participate in the response processes to damage, such as defending against infectious agents and regulating the function of a number of cellular signaling systems [21], though 
they would even fulfill an indirect antioxidant function at $\mathrm{H}_{2} \mathrm{O}_{2}$ concentrations between 1 and $10 \mathrm{nmol} / \mathrm{L}$ via the Nrf2 pathway [22]. On the other hand, at concentrations greater than $100 \mathrm{nmol} / \mathrm{L}$, the nuclear factor kappa-light-chain-enhancer of the activated B cells (NF-kB) pathway is activated, which is the major mediator of cytokine effects in the heart, and is involved in damaging processes [14,22].

\subsection{Pathophysiology of Cardiac Ischemia/Reperfusion Injury}

Patients with AMI present a complete arrest of blood flow in specific regions of the heart, with PCI therapy being the gold standard procedure for the blood flow restoration. However, both the ischemia and reperfusion processes cause multiple energetic and biochemical changes in the cells of the myocardial tissue. These effects have been associated with multiple complications, such as lethal reperfusion, no-reflow phenomenon, myocardial stunning, and reperfusion arrhythmias [23].

The absence of oxygen caused by the ischemic period induces a decrease in adenosine triphosphate (ATP) synthesis due to a lower activity of oxidative phosphorylation, which is accompanied by an increased anaerobic metabolism, thus increasing the formation of lactic acid [24,25] and decreasing the metabolic activity of the Krebs cycle. There is also a decrease in intracellular $\mathrm{pH}$ that, concomitant with the ATP depletion, causes a decrease in cardiac contractile activity [26] and multiples ionic changes that culminate in a cytosolic overload [27]. This is due to the overwhelming of the sarcoplasmic reticulum $\mathrm{Ca}^{2+}$ ATPase that, under these circumstances, is unable to counteract the increased cytosolic $\mathrm{Ca}^{2+}$ concentration [28]. In addition, xanthine dehydrogenase is converted to $\mathrm{XO}$, a source of $\mathrm{O}_{2} \cdot-$ that induces oxidative stress, increasing intracellular calcium, and the mitochondrial permeability transition pore ( $\mathrm{mPTP})$ is inhibited as a result of acidic conditions [29].

During reperfusion, blood flow restoration leads to the recovery of mitochondrial respiration and intracellular $\mathrm{pH}$ [24]. As a consequence, an ROS burst occurs during the first minutes following the onset of reperfusion [30]. This event has been considered one the key contributing factors accounting for cardiac tissue injury by $I / R$, as it is able to trigger mechanisms of cell death in different cell types of cardiac tissue [15,31]. Indeed, the main sources leading to an increased ROS production during reperfusion correspond to the impaired mitochondrial electron transport chain, namely NOX in neutrophils and $\mathrm{XO}$ and un-eNOS in endothelial cells [32] (Figure 1). However, other potential sources have also been described, such as cytochrome P450, lipoxygenase, cyclooxygenase, and monoamine oxidase [33]. Furthermore, during the MIRI process, iron mobilization occurs, which increases the concentrations of the labile iron pool that, in turn, can promote the occurrence of Fenton reactions and the production of $\cdot \mathrm{OH}$ (Figure 1). Several pathways can contribute to an increase in the cytosolic free iron that has been described in MIRI, such as ferritinophagy [34], polyol pathway [35], myocardial hemorrhage [36], Fe-S cluster [37], and heavy ferritin chain [38], all of which would finally induce ferroptosis in cardiac tissue [39].

In addition, it was shown that the opening of $\mathrm{MPTP}$ occurs within the first few minutes following the onset of reperfusion [40], possibly due to both the burst of oxidative stress and the restoration of $\mathrm{pH}$ as the main contributing factors [41,42], which initially remains inhibited by acidic conditions during ischemia [29]. In this same line, a previous study showed that the early induction of temporary acidosis during reperfusion reduced infarct size in dogs [43]. However, the role of the molecular identity of mPTP is still a matter of discussion, where proteins such as adenine nucleotide translocase and FOF1-ATP synthase have been proposed to be involved, but the capacity for inducing cell death remains unclear $[44,45]$. Nevertheless, mPTP plays a crucial role in the pathogenesis of MIRI and has been described as a potential pharmacological target, since its inhibition was shown to reduce the infarct size by $40-50 \%$ [46-49]. 


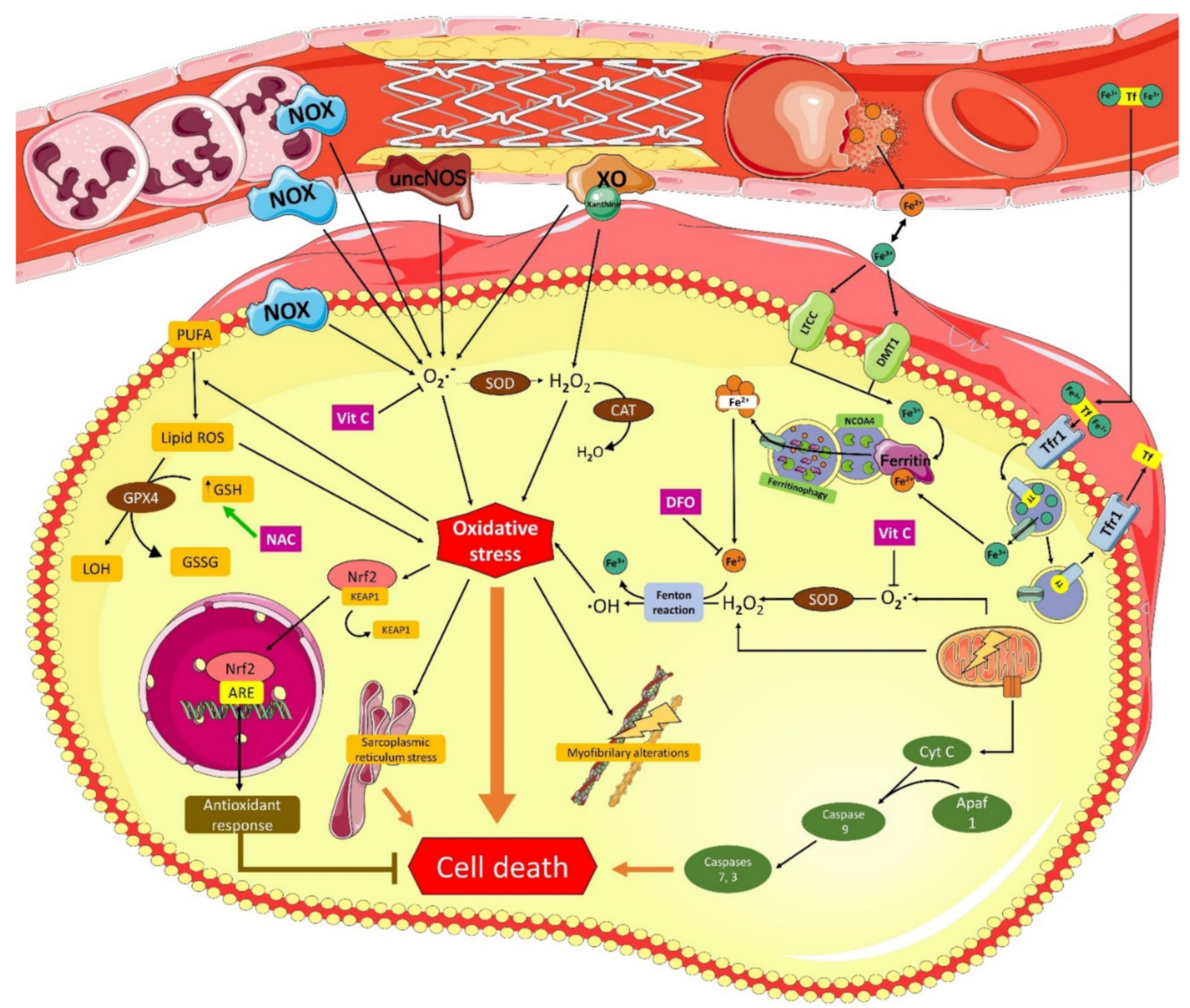

Figure 1. Molecular mechanisms of the deleterious effects of myocardial reperfusion injury and proposed target of combined antioxidant therapy: Apaf1, apoptosis protease-activating factor-1; ARE, antioxidant response element; CAT, catalase; Cyt C, cytochrome c; DFO, deferoxamine; DMT1, divalent metal transporter 1; GPX, glutathione peroxidase; GSH, reduced glutathione; GSSG, oxidized glutathione; KEAP1, Kelch-like ECH-associated protein 1; LTCC, L-type calcium channel; LOH, lipid alcohols; NAC, N-acetyl-L-cysteine; NCOA4, nuclear receptor coactivator 4; Nrf2, nuclear factor-erythroid 2-related factor 2; NOX, reduced nicotinamide adenine dinucleotide phosphate oxidase; PUFA, polyunsaturated fatty acids; ROS, reactive oxygen species; $S O D$, superoxide dismutase; $T f$, transferrin; TfR1, transferrin receptor protein 1; Vit $C$, vitamin $C$; $\mathrm{XO}$, xanthine oxidase.

Myocardial ischemia-reperfusion injury has also been significantly linked to inflammation, although it is not yet clear whether the participation of the inflammatory response that accompanies AMI contributes to the pathogenesis of reperfusion injury or whether it is just an epiphenomenon [50,51]. However, the upregulation of adhesion molecules (P-selectin, CD11/CD18, and ICAM-1) in cardiomyocytes and cytokines (TNF $\alpha$, IL-1, IL-6, IL-8, NAP-1, $\mathrm{PAF}$, and MIP-2), and the complement during reperfusion, has been reported, promoting the arrival of neutrophils to the infarcted areas of the myocardium [52]. Neutrophils release more than 20 different proteolytic enzymes and are a major ROS source by generating superoxide anions through NOX, thus they would have an important role in the MIRI [52]. Moreover, the increase in the formation of inflammatory molecules has been linked to the activation of the NF- $\mathrm{kB}$ pathway due to cytokines and oxidative stress produced by the ROS burst during reperfusion [51,53-55]. Furthermore, it has recently been shown that cell death by ferroptosis, as a result of $\mathrm{I} / \mathrm{R}$ in a mouse heart transplantation model, initiates the recruitment of neutrophils through the TLR4/TRIF signaling pathway [56]. 


\section{Cardioprotection by Vitamin C}

Vitamin C (Figure 2, Table 1) is a water-soluble antioxidant compound, which fulfills essential functions in humans by being a component of the antioxidant defense system. It reduces compounds such as free radicals through its electron donating capacity, being oxidized to dehydroascorbate. Normal plasma Vit C levels are around 50-70 $\mu \mathrm{mol} / \mathrm{L}$ [8] and are not synthesized by the human body, therefore its intake through food, such as fruits and vegetables, is the prevalent source for humans. In addition, it can be administered as a supplement, orally or intravenously. As Vit $C$ is a water-soluble molecule, it needs transporters to be able to exert its effects within the cell. Two $\mathrm{Na}^{+}$-dependent transporters (SVCT1 and SVCT2) have been described as those responsible for the intracellular uptake of Vit C, while dehydroascorbate enters through GLUT family transporters, such as GLUT1, GLUT3, and GLUT4 [57] (Figure 3). Therefore, it is important to mention that human myocardium contains GLUT1, GLUT3, and GLUT4 [58].

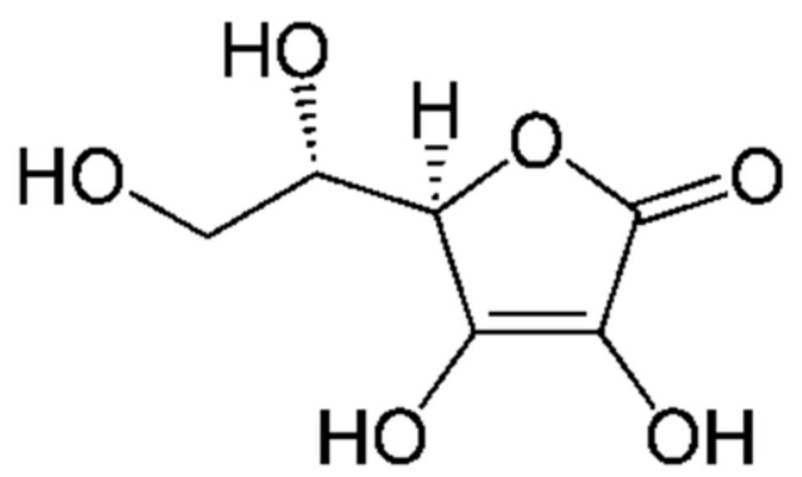

Figure 2. Molecular structure of vitamin C.

From early studies, the use of Vit $C$ has been proposed to counteract the oxidative stress produced by the cardiac I/R process in order to reduce the heart damage (Table 1 ), where it has been described that patients undergoing PCI suffer from a depletion of Vit $C$ [59]. Several in-vitro experiments have shown the benefits of the ROS-scavenging capacity of Vit C [60], while its intra-arterial administration in high doses was found to suppress the in-vivo effects of superoxide anions on vascular endothelial dysfunction in subjects with essential hypertension [61,62]. A study showed that AMI patients undergoing thrombolysis had decreased SOD enzyme activity along with increased XO enzyme activity and malondialdehyde (MDA) levels after reperfusion, which was restored to normal or near-normal levels by oral administration of Vit $C$ after reperfusion [63]. Clinical trials have also been carried out wherein post-perfusion Vit $C$ has been used in patients undergoing PCI. However, although they have mainly achieved the objective of reducing the biomarkers of oxidative stress, they have not been able to reduce the infarct size [9].

\subsection{Parameters Studied in Clinical Trials}

The results obtained from the administration of Vit $C$ to reduce post-PCI injury can be described based on four parameters: First in the biomarkers of oxidative stress and inflammation, benefits in cardiac function, reduction of cardiac damage, and finally the infarct size. These will be discussed below. 


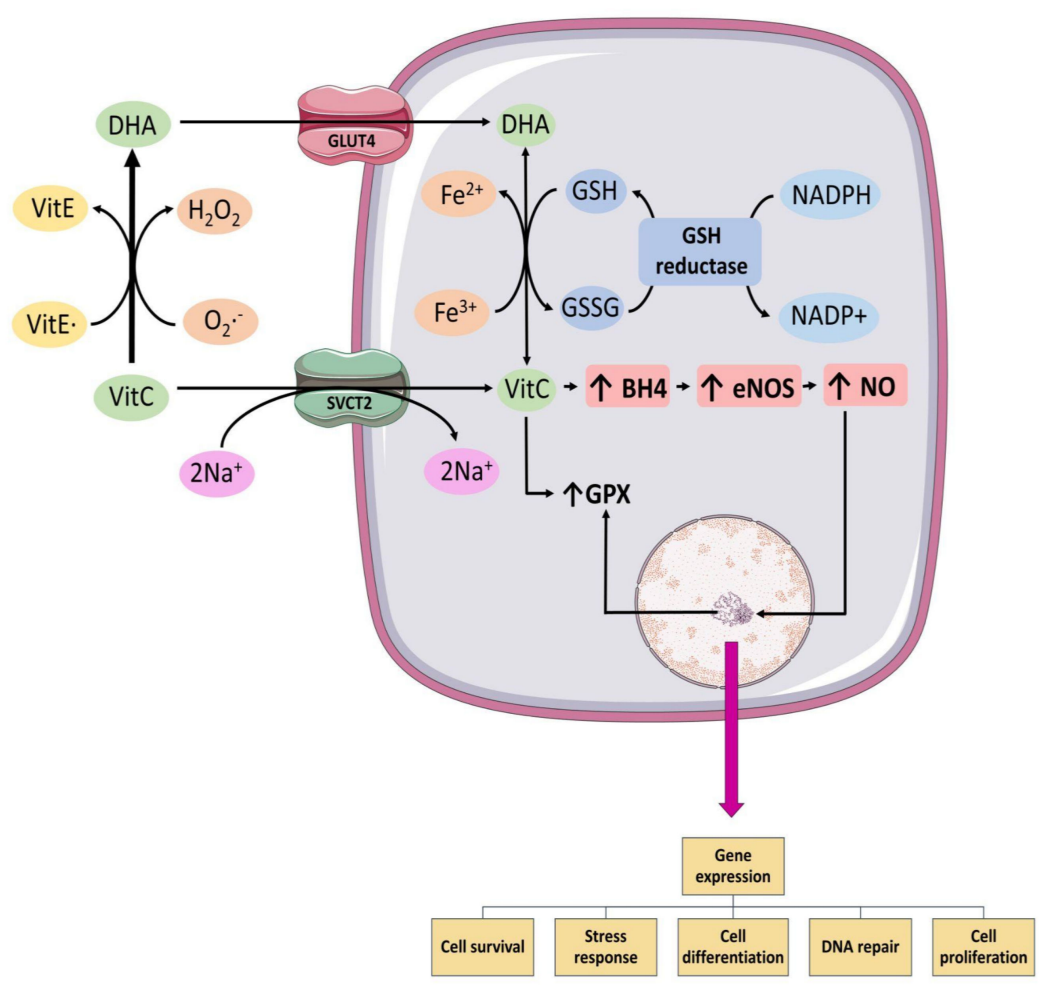

Figure 3. Mechanism of Vit $C$ uptake and its effects in the cell: Reduced form of Vit $C$ is transported through sodium-dependent transporter (SVCT2) and oxidized form, dehydroascorbic acid (DHA), is transported through GLUT4. Inside the cell, DHA is reduced back to Vit C. Vit C increases levels of tetrahydrobiopterin (BH4), levels which are a cofactor for endothelial nitric oxide synthase (eNOS) coupling and important for nitric oxide (NO) synthesis. AA, ascorbic acid; $\mathrm{BH} 4$, tetrahydrobiopterin; DHA, dehydroascorbic acid; eNOS, endothelial nitric oxide synthase; GLUT 4, type 4 glucose transporter; GPX, glutathione peroxidase; NO, nitric oxide; SVCT2, sodium-dependent vitamin C transporter 2; Vit E, $\alpha$-tocopherol: Vit E* $\alpha$-tocopheroxyl radical.

\subsubsection{Oxidative Stress and Inflammation Biomarkers}

The measurement of oxidative stress biomarkers is one of the main parameters that are analyzed in clinical trials and studies in animals and cell cultures, assessing the effects of Vit C administration (Table 1). To this extent, different biomarkers can be used, among which those organic molecules are formed upon ROS attack to biomolecules such as lipids, proteins, or DNA and those that are related to the antioxidant capacity of the patient at the plasma and cellular levels. Clinical trials that have administered Vit $C$ to reduce reperfusion injury after PCI have shown favorable results through significant decreases in oxidative stress biomarkers such as lactate dehydrogenase (LDH) after measuring them in blood samples at different post-PCI times [9]. It should be mentioned that molecules derived from lipid peroxidation are one of the main used biomarkers. Following Vit $\mathrm{C}$ administration, both a significant decrease in hydroperoxides concentration at $48 \mathrm{~h}$ post reperfusion [16] and a decrease in 8 -isoprostanes after $6-8 \mathrm{~h}$ post-PCI were shown [64]. Another three trials showed a significant decrease in the levels of 8-hydroxy-2-deoxyguanosine after $1 \mathrm{~h}[65,66], 2 \mathrm{~h}[66]$, or $6 \mathrm{~h}$ [67] post-PCI. Basili et al. also showed a significant decrease in 8-iso-prostaglandin F2alpha at 6-8 h after PCI [65]. However, Guan et al. analyzed biomarkers in urine samples, revealing that there were no significant differences between the group of patients that received Vit $C$ and the placebo group when measuring 8-hydroxy2-deoxyguanosine for different periods of time in the first $5 \mathrm{~h}$ after PCI [68].

In addition, an increase in the antioxidant response has also been observed after Vit $C$ administration during the first hours after PCI, with elevated serum ascorbate levels [64,69], a higher ferric reducing ability of plasma (FRAP) [64,69], and an increased total antioxidant capacity at $48 \mathrm{~h}$ after reperfusion, but not 1 month later [16]. However, the GSH/GSSG 
ratio decreased significantly in the groups supplemented with Vit C, having GSH levels half of those of the placebo group at $6-8 \mathrm{~h}$ after reperfusion $[64,69]$.

Another parameter that can be affected by Vit $C$ is related to inflammation, as Khan et al. [9] highlighted in their systematic review, wherein the authors suggest that the inflammatory biomarkers that have been measured in three clinical trials with Vit $C$ after PCI, together with their results, give rise to lower levels of Thromboxane B2 (TxB2), soluble NOX2-derived peptide ( $s N O X 2-d p$ ), soluble CD40 ligand (sCD40L), and platelet CD40L, but not high-sensitivity C-reactive protein (hs-CRP) and tumor necrosis factor alpha $(\mathrm{TNF} \alpha)$ when measured within a short time frame after PCI [9].

Finally, we can conclude that the use of Vit $C$ works to reduce the levels of oxidative stress after PCI, either by decreasing the levels of free radicals, or by enhancing the antioxidant system. However, this does not necessarily mean the obtaining of better outcomes in patients or a smaller infarct size. Other biomarkers should be analyzed together to obtain more certain evidence on the status of the patients' heart to give some clues of the clinical outcome.

\subsubsection{Beneficial Effects in Cardiac Function Parameters}

After seeing the results of different studies wherein Vit $C$ has been included as a treatment for AMI, one of the most outstanding aspects is represented by the beneficial effects on the parameters of cardiac function, especially in relation to the LV, such as LVEF, LV fractional shortening (LVFS), LV isovolumic relaxation time (IVRT), cardiac output, stroke volume, and ratio of early to late ventricular filling (E/A ratio). When cardiomyopathy is induced with Doxorubicin, for example, there is a loss of cardiac function and structure. These effects include an increased heart rate, alteration in the structure of cardiomyocytes, the formation and disorder of vacuoles, loss of myofibrils, alteration in the shape of the nucleus, changes in systolic function (decreases LVFS and LVEF), and compromised relaxation and filling of the LV (increases the IVRT and E/A ratio) $[9,70]$. A quite recent in-vivo study showed that Vit $C$ protects against these changes and increases survival. Indeed, the heart rate decreased, cardiac function was improved by increasing LVFS and LVEF, and protective effects were evidenced, since the formation of vacuoles was decreased and the myofibrils remained unchanged. In addition, the nucleus returned to its normal morphology and fibrosis decreased [70]. Moreover, another study suggested that Vit $C$ has a possible functional effect because it improves the change in LVEF, and that this therapy effectively ameliorates the persistent LV impairment [64,69]. However, despite the good results, these are still not homogeneous and the exact mechanisms of action of Vit $C$ on functional parameters have yet to be elucidated [64].

\subsubsection{Myocardial Damage Amelioration}

A number of biomarkers in the circulation can be used to evidence myocardial injury and cell death, such as cardiac troponin I (cTnI), cardiac troponin T (cTnT), and creatine phosphokinase MB isoenzyme (CK-MB). Changes of phosphorylation of cTnI and cTnT alter sarcomeric function [71], and both are the best options to measure myocardial injury while CK-MB is less sensitive and less specific; however, it is still useful [72]. After restoring blood flow with PCI, several studies have shown an elevation of troponins and increased CK-MB. Treatment with Vit $\mathrm{C}$ reported positive outcomes for reducing troponin and CK-MB levels, although the results are conflicting as others studies failed to show a benefit $[9,73]$.

\subsubsection{Infarct Size}

Reducing infarct size after an episode of $\mathrm{I} / \mathrm{R}$ is a widely studied target in cardiac pathophysiology. Although progress has been made in therapies, there are multiple pathways that favor an increase in the infarct size, including some that may not have been discovered yet. Cardiomyocyte cell death through apoptosis, necrosis, pyroptosis, autophagy, or ferroptosis is a central target to reduce infarct size [14,39]. However, there is still much to be elucidated, and the results are not of total consensus. One of the therapies 
used to reduce the infarct size is Vit $C$ due to its capacity to act as a ROS scavenger and reduce oxidative stress. Moreover, it can confer cardioprotection [73]. However, another study has shown that Vit $C$, given prior to reperfusion at enough dosing to reach plasma levels over $10 \mathrm{mmol} / \mathrm{L}$, did not show a significant difference in infarct size [69]. This discrepancy may be due to the fact that there are not many studies of Vit $C$ in humans (even though it has been shown to be harmless at high concentrations) (Table 1) and the lack of consideration of basic aspects such as the mechanistic approximation of the drug and its pharmacokinetics properties [14]. Thus, high Vit C doses (e.g., $10 \mathrm{mmol} / \mathrm{L}$ plasma levels, see below) are capable of reducing $\mathrm{O}_{2} \cdot{ }^{-}$production, though is not feasible in a setting of $\mathrm{I} / \mathrm{R}$ to achieve the scavenging of $\cdot \mathrm{OH}$ derived from the activation of Fenton reaction occurring in this clinical model.

\subsection{Antioxidant Mechanism of Vitamin C}

The best-known antioxidant mechanism of Vit $C$ corresponds to that of ROS scavenger. However, Vit C must reach a plasma concentration of $10 \mathrm{mmol} / \mathrm{L}$ to displace the reaction of the superoxide anion radical with nitric oxide, which acts at a rate $10^{5}$ times greater than the reaction between ascorbic acid and superoxide anion radical [74,75]. Regarding the other effects of Vit $C$, in addition to scavenge ROS, it exerts a modulatory activity on enzymes, thus indirectly decreasing the formation of ROS (Figure 3). Within these modulations, Vit C exerts a down-regulation on the activity of enzyme NOX [76], which is present in the endothelium, leukocytes, and myocardium, being responsible for producing $\mathrm{O}_{2}{ }^{\cdot-}$. Vitamin $\mathrm{C}$ can also inhibit the activation of the NF- $\mathrm{kB}$ pathway [77], thus modulating the formation of cytokines that amplify the inflammatory response that normally promotes the arrival of more leukocytes and thus increases ROS formation and damage when this pathway is active. Vitamin C also prevents the uncoupling of the eNOS enzyme by stabilizing tetrahydrobiopterin (BH4) along with preventing its oxidation [78] (Figure 3). Normally, when $\mathrm{BH} 4$ is oxidized, it causes eNOS to uncouple and begin to synthesize radical $\mathrm{O}_{2}{ }^{-}-$ instead of NO', thus enhancing oxidative stress [79]. Moreover, impaired microcirculatory reperfusion is improved by Vit C [65].

In addition, Vit $C$ enhances the antioxidant response where it allows for the recycling of alpha-tocopherol in the interphase of lipid-aqueous compartments [80], lipid bilayer [81], and erythrocytes [82]. It has been described as one of the most powerful antioxidants, also being its most active form within the group of molecules of Vit E [83] (Figure 3). In addition, it has been reported that the use of oral Vit $C$ is able to restore the SOD enzyme to normal levels in patients who have suffered AMI and have been thrombolysed to reperfuse the heart [63]. However, the mechanisms remain to be elucidated.

\subsection{Considerations on the Use of Vitamin C}

Despite the previously mentioned mechanisms, the use of Vit $C$ has not produced the expected results in patients undergoing reperfusion by $\mathrm{PCI}$, which can be analyzed from various edges, being necessary to take into account a mechanistic survey of Vit $C$ and the complexity of myocardial reperfusion damage.

To start, it should be mentioned that a plasma Vit C concentration of $10 \mathrm{mmol} / \mathrm{L}$ is needed so that it can react with the superoxide anion radical, a concentration solely achieved by intravenously administration, since pharmacokinetic studies have shown a plasma concentration of only approximately $0.08 \mathrm{mmol} / \mathrm{L}$ at steady state when Vit C is orally administered in dose ranges between 200 and $2500 \mathrm{mg}$ /day [52,84]. In addition, high doses of Vit $C$ appear to have a positive safety profile, though it should be avoided in patients with renal function impairment or glucose-6-phosphate dehydrogenase deficiency $[52,85]$. It is also important to consider the time in which Vit $C$ is administered, since immediately after starting the reperfusion is when the ROS burst occurs, so a later administration could not meet the objective of ROS scavenging and thus the outcomes proposed for the patients [59]. 
It is of interest that Vit $C$ can also act as a pro-oxidant species, especially in the presence of metal ions. At high concentrations, Vit $\mathrm{C}$ is capable of reducing $\mathrm{Fe}^{3+}$ to $\mathrm{Fe}^{2+}$, the latter being an extremely dangerous ion, as it is found either in a free form or not associated with proteins such as ferritin in the cell, and promotes the formation of large amounts of $\cdot \mathrm{OH}$ via Fenton reaction [86], thus increasing oxidative stress and decreasing the concentrations of Vit C [52]. This is important in our setting of study, since, during heart I/R, there is a mobilization of iron that causes an increase in labile iron within the cells that could therefore interact with ascorbic acid and enhance the damage.

In addition, it is important to mention that Vit $C$, after being oxidized, is reduced again through the oxidation of GSH, a process which can occur directly or mediated by enzymes (Figure 3). This has been described in both human erythrocytes [87] and bovine aortic endothelial cells [88]. Therefore, it has been previously hypothesized that the use of high doses of Vit C could trigger GSH depletion due to the high recycling rate that is being exerted due to the constant oxidation of Vit $\mathrm{C}$ during reperfusion, either for acting on the ROS burst, or for the free iron mobilized during the I/R. This is supported by previous reports of a significant decrease in the GSH/GSSG ratio in human erythrocytes in clinical trials where high doses of Vit C were used after PCI [64,69].

Finally, a couple of years ago, some authors hypothesized that a multitarget therapy is necessary to be able to fully achieve a benefit in patients subjected to cardiac reperfusion, since AMI is a multifactorial process, wherein cardiomyocytes die through various pathways, such as apoptosis, necrosis, autophagy, and necroptosis [11], and where, with the passing of time, the list is enlarged, describing new pathways that could be triggering cell death after the reperfusion injury, such as ferroptosis [39,89] and pyroptosis [90]. Furthermore, not only cardiomyocytes are affected, but also other heart cell types, such as fibroblasts, immune cells, endothelial cells, and platelets [11], and targeting only one mechanism at a time may be insufficient to produce a strong and robust effect in clinical situations where many uncontrolled variables usually coexist. Therefore, the use of Vit C as a monotherapy would not be enough to reduce myocardial reperfusion damage, given the multifactorial process of damage. Vitamin $C$ would only reduce oxidative stress under certain conditions and would not act on all the factors involved, such as the increased iron concentration. The entire cascade of damage results from a great increase in oxidative stress that can finally induce ferroptosis, as well as GSH depletion, probably caused by Vit $\mathrm{C}$ itself, all of which can weaken the antioxidant response. Due to this, therapies that are directed on different targets that establish an additive or synergistic effect could be the best option to finally reduce the MIRI and the infarct size [11].

Table 1. Results of the use of Vit $C$ alone or in association with other antioxidants.

\begin{tabular}{|c|c|c|c|}
\hline Model & Dose & Results & Ref. \\
\hline \multicolumn{4}{|c|}{ Human Models } \\
\hline $\begin{array}{l}\text { Human } \\
\text { (in vivo) }\end{array}$ & $16.6 \mathrm{mg} / \mathrm{min}$, over $1 \mathrm{~h}$ before PCI & $\begin{array}{c}\text { Better preservation of CF } \\
\text { No changes in HR, cTnT and MAP } \\
\text { Better perfusion } \\
\downarrow \text { CK-MB levels } \\
\downarrow \text { Oxidative stress }\end{array}$ & [65] \\
\hline $\begin{array}{l}\text { Human } \\
\text { (in vivo) }\end{array}$ & $\begin{array}{l}500 \mathrm{mg} \text {, } \\
\text { twice a day for } 5 \text { days before analysis }\end{array}$ & $\begin{array}{l}\uparrow \text { SOD activity } \\
\uparrow \text { Thiol levels } \\
\downarrow \text { XO activity } \\
\downarrow \text { MDA }\end{array}$ & [63] \\
\hline $\begin{array}{l}\text { Human } \\
\text { (in vivo) }\end{array}$ & $\begin{array}{c}\text { Multivitamin therapy } \\
\text { Before reperfusion: } \\
\text { Vit C, } 1 \mathrm{~g} \text { in IV bolus. } \\
\text { After reperfusion } \\
\text { (daily, for } 1 \text { month, via oral): } \\
\text { Vit C } 1 \mathrm{~g} \text {, Vit A } 50,000 \text { Unit, Vit E } 300 \mathrm{mg}\end{array}$ & $\begin{array}{c}\text { Better preservation of cardiac function } \\
\downarrow \begin{array}{c}\downarrow \text { Oxidative stress } \\
\uparrow \text { Antioxidant status }\end{array}\end{array}$ & [16] \\
\hline $\begin{array}{l}\text { Human } \\
\text { (in vivo) }\end{array}$ & $\begin{array}{c}\text { Initial dose of } 2000 \mathrm{mg} \\
\text { followed by a constant infusion at } 20 \mathrm{mg} / \mathrm{min} \\
\text { before PCI }\end{array}$ & No suppression of oxidative stress & {$[68]$} \\
\hline
\end{tabular}


Table 1. Cont.

\begin{tabular}{|c|c|c|c|}
\hline Model & Dose & Results & Ref. \\
\hline $\begin{array}{l}\text { Human } \\
\text { (in vivo) }\end{array}$ & $\begin{array}{l}1 \mathrm{~g} / \mathrm{L} \text { at } 24 \mathrm{mg} / \mathrm{min} \\
\mathrm{IV} \text { infusion }\end{array}$ & $\begin{array}{c}\text { Better preservation of CF } \\
\text { cTnT was similar between control and Vit } \\
\text { C group } \\
\downarrow \text { Oxidative stress }\end{array}$ & [66] \\
\hline $\begin{array}{l}\text { Human } \\
\text { (in vivo) }\end{array}$ & $\begin{array}{l}\text { IV infusion of } 320 \mathrm{mM} \text { at a flow rate of } 10 \mathrm{~mL} / \mathrm{min} \\
\text { during the initial hour and at } 3 \mathrm{~mL} / \mathrm{min} \text { during } \\
\text { the following } 2 \mathrm{~h} \text {. } \\
\text { After the primary PCI, oral doses of Vit C } \\
(500 \mathrm{mg} / 12 \mathrm{~h} \text { ) and } \alpha \text {-tocopherol ( } 400 \mathrm{IU} / \text { day) for } \\
84 \text { continuous days }\end{array}$ & $\begin{array}{c}\text { No significant difference in infarct size } \\
\text { between the groups } \\
\text { Better preservation of CF } \\
\text { No changes in CK-MB } \\
\uparrow \text { FRAP levels }\end{array}$ & [69] \\
\hline $\begin{array}{l}\text { Human } \\
\text { (in vivo) }\end{array}$ & $\begin{array}{l}\text { Initial dose of } 3 \mathrm{~g} \mathrm{IV} \text { before } \mathrm{PCI} \text { and } 100 \mathrm{mg} \text { of } \\
\text { intracoronary Vit C during PCI }\end{array}$ & $\downarrow$ cTnT and CK-MB levels & [73] \\
\hline $\begin{array}{l}\text { Human } \\
\text { (in vivo) }\end{array}$ & $\begin{array}{l}\text { Initial unique oral dose of } \alpha \text {-tocopherol ( } 800 \mathrm{IU}) \\
\text { and IV infusion of Vit } C \text { ( } 320 \mathrm{mM} \text { ) infused at a } \\
10 \mathrm{~mL} / \mathrm{min} \text { flow rate during the first hour and at a } \\
3 \mathrm{~mL} / \mathrm{min} \text { rate during the following } 2 \mathrm{~h} \text {. } \\
\text { After the PCI, oral doses of } \\
\text { Vit } \mathrm{E} \text { ( } 400 \mathrm{IU} / \text { day) and Vit } \mathrm{C}(500 \mathrm{mg} / 12 \mathrm{~h} \text { ) were } \\
\text { taken by the patients for } 84 \text { continuous days. }\end{array}$ & $\begin{array}{l}\text { Better preservation of CF } \\
\text { No differences in CK-MB } \\
\uparrow \text { FRAP levels }\end{array}$ & [64] \\
\hline $\begin{array}{l}\text { Human } \\
\text { (in vivo) }\end{array}$ & $3 \mathrm{~g} \mathrm{IV}$ within $6 \mathrm{~h}$ before PCI & $\begin{array}{c}\downarrow \text { cTnT and CK-MB levels } \\
\quad \downarrow \text { Oxidative stress }\end{array}$ & [67] \\
\hline \multicolumn{4}{|c|}{ Animal models } \\
\hline $\begin{array}{l}\text { Adult mongrel dogs } \\
\quad \text { (in vivo) }\end{array}$ & $\begin{array}{c}100 \mathrm{mg} / \mathrm{kg} \text { of Vit } \mathrm{C} \text { was administered just before } \\
\text { reperfusion }\end{array}$ & $\begin{array}{c}\downarrow \text { Mortality in group of supplemented } \\
\text { dogs } \\
\uparrow \text { GSH/GSSG ratio } \\
\text { No significant changes in activities of GPX } \\
\text { and GR }\end{array}$ & [91] \\
\hline $\begin{array}{l}\text { Domestic pigs } \\
\text { (in vivo) }\end{array}$ & $\begin{array}{c}\text { Combined treatment of } 4.4 \mathrm{~g} \text { of Vit } \mathrm{C} \text { (about } \\
0.1 \mathrm{gm} / \mathrm{kg} \text { ) and } 12 \mathrm{~g} \text { of Vit } \mathrm{E} \text { acetate was infused }\end{array}$ & $\begin{array}{l}\downarrow \text { Infarct size, but just reached the border } \\
\text { of significance }\end{array}$ & [92] \\
\hline & & $\begin{array}{c}\text { AA } \\
\text { Slightly } \downarrow \text { myocardial TBAR contents }\end{array}$ & \\
\hline $\begin{array}{l}\text { Langendorff model using } \\
\text { isolated rat hearts } \\
\text { (ex vivo) }\end{array}$ & $\begin{array}{l}\text { At the time of reperfusion one group was infused } \\
\text { with } 1 \mathrm{mM} \text { of AA and another group with } 1 \mathrm{mM} \text { of } \\
\text { AA plus } 1 \mathrm{mM} \text { of GSHme }\end{array}$ & $\begin{array}{c}\text { AA plus GSHme } \\
\uparrow \text { GSH content } \\
\text { HR and CF were recovered } \\
\downarrow \text { Incidence of VF } \\
\downarrow \text { Myocardial CK loss } \\
\downarrow \text { Myocardial TBARS content } \\
\downarrow \text { Myocardial nitrotyrosine }\end{array}$ & [93] \\
\hline $\begin{array}{l}\text { Young male farm pigs } \\
\text { (in vivo) }\end{array}$ & IV infusion of $100 \mathrm{mg} / \mathrm{kg} \mathrm{AA}$ and $60 \mathrm{mg} / \mathrm{kg}$ DFO & $\begin{array}{l}\text { The therapy did not provide significant } \\
\text { cardioprotection in the experimental } \\
\text { group in any of the parameters measured }\end{array}$ & [94] \\
\hline $\begin{array}{l}\text { Farm-raised domestic } \\
\text { male pigs } \\
\text { (in vivo) }\end{array}$ & $\begin{array}{l}\text { One group receive AA } 100 \mathrm{mg} / \mathrm{kg} \text { infusion. } \\
\text { Other group receive AA } 100 \mathrm{mg} / \mathrm{kg}+\mathrm{DFO} \\
60 \mathrm{mg} / \mathrm{kg}+\mathrm{NAC} 100 \mathrm{mg} / \mathrm{kg} \text { for } 20 \mathrm{~min} \text { with a } \\
20-\mathrm{mg} / \mathrm{kg} \text { maintenance dose }\end{array}$ & $\begin{array}{l}\text { The therapy did not provide significant } \\
\text { cardioprotection in the experimental } \\
\text { group in any of the parameters measured }\end{array}$ & [95] \\
\hline $\begin{array}{l}\text { Langendorff model using } \\
\text { isolated male } \\
\text { Sprague-Dawley rats } \\
\text { hearts } \\
\text { (ex vivo) }\end{array}$ & $\begin{array}{l}\text { Hearts were post-treated with } 2 \mu \mathrm{M} \text { Vit } \mathrm{C} \text { for } \\
\quad 30 \mathrm{~min} \text { after global ischemia }\end{array}$ & $\begin{array}{c}\downarrow \mathrm{I} / \mathrm{R} \text {-Induced infarct area } \\
\downarrow \text { LDH activity } \\
\text { Improved all hemodynamic variables } \\
\uparrow \mathrm{NAD}+\text {, suggested that Vit } \mathrm{C} \text { inhibited } \\
\text { mPTP opening } \\
\downarrow \text { Apoptosis } \\
\uparrow \text { Oxygen consumption }\end{array}$ & [96] \\
\hline \multicolumn{4}{|c|}{ Cell Cultures } \\
\hline $\begin{array}{l}\text { HeLa and MCF7 cells } \\
\text { (in vitro) }\end{array}$ & $\begin{array}{l}\text { HeLa cells incubated with } 1 \mathrm{mM} \text { DHA for } 1 \mathrm{~h} \text { and } \\
\text { accumulated } 4 \mathrm{mM} \text { intracellular Vit } C \text {. Conversely, } \\
\text { cells incubated with } 1 \mathrm{mM} \text { Vit } C \text { for } 1 \mathrm{~h} \\
\text { accumulated } 0.2 \mathrm{mM} \text { intracellular Vit } C^{*}\end{array}$ & $\begin{array}{c}\text { Inhibits: } \\
\text { TNF } \alpha \text {-induced transcriptional responses } \\
\text { mediated by NF- } \mathrm{B} \text { B } \\
\text { TNF-dependent nuclear translocation of } \\
\text { NF- } \mathrm{B} \text { B } \\
\text { The TNF } \alpha \text {-induced phosphorylation and } \\
\text { degradation of I } \mathrm{BR}\end{array}$ & [77] \\
\hline
\end{tabular}


Table 1. Cont.

\begin{tabular}{|c|c|c|c|}
\hline Model & Dose & Results & Ref. \\
\hline \multirow{2}{*}{$\begin{array}{l}\text { Neonatal rat cardiac } \\
\text { fibroblast } \\
\text { (in vitro) }\end{array}$} & $\begin{array}{l}\text { Cells treated with Vit } \mathrm{C} \text { in doses of } 1 \mu \mathrm{M}, 10 \mu \mathrm{M} \\
\qquad 100 \mu \mathrm{M}, 10,000 \mu \mathrm{M}\end{array}$ & $\begin{array}{c}\text { No effect in cell viability at } 1 \text { and } 10 \mu \mathrm{M} \\
\uparrow \text { Cell viability but not significantly at } \\
100 \mu \mathrm{M} \\
\downarrow \text { Cell viability at } 10,000 \mu \mathrm{M}\end{array}$ & \multirow[b]{2}{*}{ [97] } \\
\hline & $\begin{array}{l}\text { Cells treated with different combinations of Vit C, } \\
\text { DFO, NAC (Vit C/DFO, Vit C/NAC and Vit } \\
\text { C/NAC/DFO), each in doses of } 1 \text { and } 10 \mu \mathrm{M}\end{array}$ & $\begin{array}{c}\uparrow \text { Cell viability only Vit C/DFO in doses of } \\
1 \mu \mathrm{M} \\
\uparrow \text { Cell viability Vit C/DFO, Vit C/NAC } \\
\text { and Vit C/NAC/DFO in doses of } 10 \mu \mathrm{M} \\
\downarrow \text { Intracellular ROS production Vit } \\
\mathrm{C} / \mathrm{NAC} / \mathrm{DFO} \text { in doses of } 10 \mu \mathrm{M}\end{array}$ & \\
\hline $\begin{array}{l}\text { HUVEC } \\
\text { HCAEC } \\
\text { (in vitro) }\end{array}$ & $\begin{array}{l}\text { Cells were preloaded with AA by incubating with } \\
\text { different concentrations of DHA for } 30 \mathrm{~min} \text { before } \\
\text { subjecting to hypoxia }\end{array}$ & $\begin{array}{c}\downarrow \text { Apoptosis } \\
\downarrow \text { ROS levels } \\
\text { Prevents release of Cyt C to cytosol } \\
\text { Stabilizes mitochondrial membrane } \\
\text { potential } \\
\text { Inhibits procaspase-9 and procaspase-3 } \\
\text { activation }\end{array}$ & [98] \\
\hline $\begin{array}{l}\text { Neonatal rat cardiac } \\
\text { ventricular myocytes } \\
\quad \text { (in vitro) }\end{array}$ & $\begin{array}{l}\text { Cells were post-conditioned with normal culture } \\
\text { medium containing } 2 \mu \mathrm{M} \text { Vit } \mathrm{C}\end{array}$ & $\begin{array}{c}\uparrow \text { Cell viability } \\
\downarrow \text { LDH activity } \\
\downarrow \text { Cytosolic } \mathrm{Ca}^{2+} \text { overload. } \\
\downarrow \text { ROS levels } \\
\text { Alleviated mPTP opening in } \\
\text { cardiomyocytes } \\
\text { Preserved } \Delta \Psi \mathrm{m} \\
\uparrow \text { AKT (Ser473) phosphorylation } \\
\uparrow \text { Expression of p-GSK } 3 \beta \text { (Ser9) }\end{array}$ & [96] \\
\hline
\end{tabular}

* Probably due to conversion of Vit $\mathrm{C}$ to DHA under aerobic conditions: AA, ascorbic acid; CF, cardiac function; CK-MB, creatinine phosphokinase MB isoenzyme; cTnT, cardiac troponin; Cyt c, citocrome C; DHA, dehydroascorbic acid; DFO, deferoxamine; FRAP, ferric reducing ability of plasma; GPX, glutathione peroxidase; GR, glutathione reductase; GSH, reduced glutathione; GSSG, glutathione disulfide; HR, heart rate; IV, intravenously; LDH, lactate dehydrogenase; MAP, mean arterial pressure; MDA, malondialdehyde; mPTP, mitochondrial permeability transition pore; NAC, N-acetylcysteine; $\mathrm{PCI}$, percutaneous coronary intervention; ROS, reactive oxygen species; SOD, superoxide dismutase; TBAR, thiobarbituric acid reactive substances; TNF, tumor necrosis factor; Vit $A$, vitamin A; Vit C, vitamin C; Vit E, vitamin E; $X O$, xanthine oxidase; $\Delta \Psi \mathrm{m}$, mitochondrial membrane potential; $\uparrow$, increase; $\downarrow$, decrease.

\section{Cardioprotective Effects Exerted by Other Antioxidants}

Over time, various antioxidants have been used to generate cardioprotection after MIRI, such as Vit E, NAC, DFO, and polyphenols, obtaining different results in in-vivo and in-vitro studies. A widely used method to study I/R is the Langendorff model (ex vivo), which basically consists of a functionally active isolated heart having a cannula inserted into its aorta so that the heart can be retrogradely perfused via the coronary circulation [99]. On the other hand, in-vivo studies have also been performed in the hearts of living whole organisms of species such as a pig, dog, rabbit, sheep, mouse, and rat [100]. Finally, cardiac tissue cell cultures have also been subjected to study the in-vitro protective effects of antioxidant in I/R settings. The main results are summarized in Table 2.

Table 2. Results of the use of different antioxidants to reduce MIRI.

\begin{tabular}{|c|c|c|c|c|}
\hline Antioxidant & Model & Dose & Results & Ref. \\
\hline \multirow[t]{2}{*}{$\begin{array}{c}\text { Vit E } \\
\alpha \text {-tocopherol } \\
\left(\mathrm{C}_{29} \mathrm{H}_{50} \mathrm{O}_{2}\right)\end{array}$} & $\begin{array}{l}\text { C57BL } / 6 \text { mice } \\
\text { (in vivo) }\end{array}$ & $\begin{array}{l}2.5 \mathrm{mg} / \mathrm{kg} \mathrm{BW} \text { in } \\
0.8 \% \text { DMSO } 2 \mathrm{~h} \\
\text { prior to surgery, } \\
\text { immediately after } \\
\text { PCI, and twice per } \\
\text { day for three } \\
\text { consecutive days }\end{array}$ & $\begin{array}{c}\downarrow \text { Infarct size } \\
\downarrow \text { ROS and lipid oxidation } \\
\downarrow \text { MPO activity } \\
\downarrow \text { Neutrophil infiltration } \\
\text { Prevented pathological } \\
\text { changes }\end{array}$ & [101] \\
\hline & $\begin{array}{c}\text { Langendorff model } \\
\text { using male Hartley } \\
\text { Guinea pigs hearts } \\
\text { (ex vivo) }\end{array}$ & $100 \mu \mathrm{M}$ & $\begin{array}{c}\text { QT segment recovered } \\
10 \%\end{array}$ & [102] \\
\hline
\end{tabular}


Table 2. Cont.

\begin{tabular}{|c|c|c|c|c|}
\hline Antioxidant & Model & Dose & Results & Ref. \\
\hline \multirow[b]{2}{*}{$\begin{array}{c}\mathrm{NAC} \\
\left(\mathrm{C}_{5} \mathrm{H}_{9} \mathrm{NO}_{3} \mathrm{~S}\right)\end{array}$} & Human (in vivo) & $\begin{array}{l}\text { IV bolus of } \\
1200 \mathrm{mg} \text { before PCI } \\
\text { and } 1200 \mathrm{mg} \text { IV } \\
\text { twice daily for the } \\
48 \mathrm{~h} \text { after PCI (total } \\
\text { dose } 6000 \mathrm{mg} \text { ) }\end{array}$ & $\begin{array}{l}\downarrow \text { Oxidative stress } \\
\text { It does not provide an } \\
\text { additional clinical benefit } \\
\text { to placebo with respect to } \\
\text { patients undergoing PCI. } \\
\text { No adverse effects. }\end{array}$ & [103] \\
\hline & $\begin{array}{l}\text { Human } \\
\text { (in vivo) }\end{array}$ & $\begin{array}{l}\text { Patients with AMI } \\
\text { received } 15 \mathrm{~g} \\
\text { infused over } 24 \mathrm{~h}+ \\
\text { IV NTG and } \\
\text { streptokinase }\end{array}$ & $\begin{array}{c}\downarrow \text { Oxidative stress. } \\
\text { NAC and GSH } \\
\text { concentration were } \\
\text { correlated. } \\
\downarrow \text { MDA concentrations } \\
\text { over the first } 8 \mathrm{~h} \text { of } \\
\text { treatment. } \\
\text { Better preservation of LV } \\
\text { function. } \\
\text { No adverse effects. }\end{array}$ & [104] \\
\hline \multirow{2}{*}{$\begin{array}{c}\mathrm{NAC} \\
\left(\mathrm{C}_{5} \mathrm{H}_{9} \mathrm{NO}_{3} \mathrm{~S}\right)\end{array}$} & Human (in vivo) & $\begin{array}{l}\text { NAC } 100 \mathrm{mg} / \mathrm{kg} \\
\text { bolus followed by } \\
\text { intracoronary } \\
\text { NAC } 480 \mathrm{mg} \\
\text { during PCI then IV } \\
\text { NAC } 10 \mathrm{mg} / \mathrm{kg} \text { for } \\
12 \mathrm{~h}\end{array}$ & $\begin{array}{c}\downarrow \text { Peak hs-TnT level after } \\
\text { PCI. } \\
\text { Difference in peak CK-MB } \\
\text { was not statistically } \\
\text { significant. } \\
\text { No adverse effects }\end{array}$ & [105] \\
\hline & $\begin{array}{l}\text { Human } \\
\text { (in vivo) }\end{array}$ & $\begin{array}{c}\text { Infusion of } \\
50 \mathrm{mg} / \mathrm{kg} \\
\text { followed by IV } \\
\text { infusion for } 48 \mathrm{~h} \\
\text { after the operation } \\
\text { at a dose of } \\
50 \mathrm{mg} / \mathrm{kg} / \text { day }\end{array}$ & $\begin{array}{l}\downarrow \text { Rate of atrial fibrillation } \\
\text { in the NAC group. }\end{array}$ & [106] \\
\hline \multirow[t]{2}{*}{$\begin{array}{c}\mathrm{DFO} \\
\left(\mathrm{C}_{25} \mathrm{H}_{48} \mathrm{~N}_{6} \mathrm{O}_{8}\right)\end{array}$} & $\begin{array}{l}\text { Human } \\
\text { (in vivo) }\end{array}$ & $\begin{array}{l}4 \mathrm{~g} \text { were infused } \\
\text { for } 8 \mathrm{~h}\end{array}$ & $\begin{array}{c}\text { Prevented ROS } \\
\text { production } \\
\text { Improved LVEF } \\
\text { No major cardiac event } \\
\text { was reported with long } \\
\text { term administration } \\
\end{array}$ & [107] \\
\hline & $\begin{array}{l}\text { Human } \\
\text { (in vivo) }\end{array}$ & $\begin{array}{c}500 \mathrm{mg} 5 \text { to } 10 \mathrm{~min} \\
\text { before PCI, } \\
\text { followed by } \\
50 \mathrm{mg} / \mathrm{kg} \text { over } \\
12 \mathrm{~h}\end{array}$ & $\begin{array}{l}\downarrow \text { Serum iron and plasma } \\
\text { F2-isoprostane levels } \\
\text { during the first hours. } \\
\text { No changes in the infarct } \\
\text { size. }\end{array}$ & [108] \\
\hline \multirow{3}{*}{$\begin{array}{l}\text { Polyphenols } \\
\text { (Flavonols) }\end{array}$} & $\begin{array}{c}\text { Cells suspension of } \\
\text { rats } \\
\text { (Wistar strain) } \\
\text { Thymocytes } \\
\text { (in vitro) }\end{array}$ & $\begin{array}{c}2 \mathrm{~mL} \text { cell } \\
\text { suspension in a } \\
10 \text { mL test tube }\end{array}$ & $\begin{array}{l}\text { Protective effect on the } \\
\text { cells suffering oxidative } \\
\text { stress and cells suffering } \\
\text { from intracellular } \mathrm{Ca}^{2+} \\
\text { overload. } \\
\downarrow \text { Cell death }\end{array}$ & [109] \\
\hline & $\begin{array}{l}\text { Langendorff model } \\
\text { using male Wistar } \\
\text { rat hearts } \\
\text { (ex vivo) }\end{array}$ & $15 \mu \mathrm{M}$ & $\begin{array}{l}\text { Improvement in the } \\
\text { functional parameters of } \\
\text { the heart (LVDP and } \\
\text { contractility) } \\
\downarrow \text { End-diastolic pressure. }\end{array}$ & [110] \\
\hline & $\begin{array}{l}\text { Human } \\
\text { (in vivo) }\end{array}$ & $\begin{array}{l}500 \mathrm{mg} \text { twice daily } \\
\text { for } 1 \text { month }\end{array}$ & $\downarrow$ Inflammation & [111] \\
\hline
\end{tabular}


Table 2. Cont

\begin{tabular}{|c|c|c|c|c|c|}
\hline Ant & idant & Model & Dose & Results & Ref. \\
\hline \multirow[t]{2}{*}{$\begin{array}{l}\text { Polyphenols } \\
\text { (Stilbenes) }\end{array}$} & \multirow[t]{2}{*}{$\begin{array}{l}\text { Resveratrol } \\
\left(\mathrm{C}_{14} \mathrm{H}_{12} \mathrm{O}_{3}\right)\end{array}$} & $\begin{array}{c}\text { Male rats } \\
\text { (Sprague-Dawley) } \\
\text { (in vivo) }\end{array}$ & $100 \mu \mathrm{M}$ & $\begin{array}{c}\downarrow \text { Infarct size, } \\
\downarrow \text { Myocardial apoptosis } \\
\downarrow \text { NF- } \mathrm{B} \text { expression } \\
\downarrow \text { Neutrophil infiltration } \\
\downarrow \text { TNF- } \alpha \text { levels } \\
\downarrow \text { Cardiac dysfunction } \\
\downarrow \text { Activity of serum } \\
\text { CK-MB and LDH level } \\
\downarrow \text { MDA levels } \\
\uparrow \text { Antioxidant enzymes } \\
\text { activities } \\
\uparrow \text { Nrf2 and HO-1 }\end{array}$ & {$[112,113]$} \\
\hline & & $\begin{array}{c}\text { Male rats } \\
\text { (Sprague-Dawley) } \\
\text { (in vivo) }\end{array}$ & $\begin{array}{l}2.5,5 \text {, and } \\
10 \mathrm{mg} / \mathrm{kg}\end{array}$ & $\begin{array}{c}\downarrow \text { Necrotic area } \\
\downarrow \text { TnT and CK-MB release } \\
\downarrow \text { IL-1 } \beta \text { and IL-18 release } \\
\downarrow \text { Myocardial NALP3 } \\
\text { expression Inhibits } \\
\text { I/R-mediated myocardial } \\
\text { Caspase1 expression. }\end{array}$ & [114] \\
\hline \multirow{4}{*}{$\begin{array}{l}\text { Polyphenols } \\
\text { (Anthocyanins) }\end{array}$} & \multirow[t]{2}{*}{$\frac{\mathrm{C} 3 \mathrm{OG}}{\left(\mathrm{C}_{21} \mathrm{H}_{21} \mathrm{O}_{11}^{+}, \mathrm{Cl}^{-}\right)}$} & \multirow[t]{2}{*}{$\begin{array}{l}\text { Langendorff model } \\
\text { (ex vivo) using } \\
\text { hearts from male } \\
\text { rats (Wistar) }\end{array}$} & $20 \mu \mathrm{M}$ & $\begin{array}{c}\downarrow \text { Cardiomyocyte death } \\
\downarrow \text { LDH levels } \\
\text { Protection against } \\
\text { apoptosis induced by I/R } \\
\text { Cytochrome c-reducing } \\
\text { activity } \\
\text { Stimulation of } \\
\text { mitochondrial respiration } \\
\text { after ischemia }\end{array}$ & \multirow{4}{*}{ [115] } \\
\hline & & & $40 \mu \mathrm{M}$ & $\begin{array}{c}\text { No significant changes } \\
\text { compared to } 20 \mu \mathrm{M} \text { of } \\
\text { C3OG }\end{array}$ & \\
\hline & \multirow[t]{2}{*}{$\begin{array}{c}\text { P3OG } \\
\left(\mathrm{C}_{21} \mathrm{H}_{21} \mathrm{O}_{10}{ }^{+}\right)\end{array}$} & \multirow{2}{*}{$\begin{array}{l}\text { Langendorff model } \\
\text { (ex vivo) using } \\
\text { hearts from male } \\
\text { rats (Wistar) }\end{array}$} & $20 \mu \mathrm{M}$ & $\begin{array}{l}\text { Cardiomyocyte death was } \\
\text { not statistically different } \\
\text { from the I/R control group } \\
\uparrow \text { LDH activity than in the } \\
\text { control group and similar } \\
\text { to the I/R group }\end{array}$ & \\
\hline & & & $40 \mu \mathrm{M}$ & $\begin{array}{l}\text { No significant changes } \\
\text { compared to } 20 \mu \mathrm{M} \text { of } \\
\text { P3GO }\end{array}$ & \\
\hline
\end{tabular}

AMI, acute myocardial infarction; C3OG, Cyanidin-3-O-glucoside; CK-MB, creatinine phosphokinase MB isoenzyme; DFO, deferoxamine; DMSO, dimethylsulfoxide; GSH, reduced glutathione; HO-1, heme oxygenase-1; IL, Interleukin; IV, instravenously LDH, lactate dehydrogenase; LV, left ventricule; LVDP, left ventricular diastolic pressure; LVEF, left ventricular ejection fraction; MDA, Malondialdehyde; MPO, Myeloperoxidase; NAC, N-acetylcysteine; NALP3, NLRP3 inflammasome; NF- $\kappa B$, nuclear factor kappa-light-chain-enhancer of activated B cells; NTG, nitroglycerin; Nrf2, nuclear factor-erythroid 2-related factor 2; P3OG, Pelargonidin-3-O-glucoside; PCI, percutaneous coronary intervention; ROS, reactive oxygen species; TNF- $\alpha$, tumor necrosis factor alpha; TnT, troponin T; Vit E, vitamin E; $\uparrow$, increase; $\downarrow$, decrease.

\subsection{Vitamin $E$}

Vitamin E (Figure 4) is a group of lipid-soluble agents with antioxidant and antiinflammatory effects, where $\alpha$-tocopherol has been described as one of the most active and effective forms in terms of antioxidant power [83]. Its antioxidant mechanisms are mainly based on its ability to act as an ROS scavenger and contribute to enzymatic regulation, such as increasing the activity of glutathione peroxidase and decreasing the release of ROS through the down-regulation of NOX [76]. Regarding its anti-inflammatory mechanism, 
it is important to mention its property to inhibit the transcriptional activity of NF- $\mathrm{kB}$ factor $[75,116]$.<smiles>Cc1c(C)c2c(c(C)c1O)CC[C@@](C)(CCC[C@H](C)CCC[C@H](C)CCCC(C)C)O2</smiles>

Figure 4. Molecular structure of $\alpha$-tocopherol.

Vitamin E has demonstrated cardioprotection in models of pathologies related to oxidative stress, such as arterial hypertension, AMI, and postoperative atrial fibrillation. Regarding its use to reduce damage due to myocardial reperfusion, different results have been obtained that are not conclusive, however Lassnigg et al. [94] carried out a clinical trial wherein the concentration of Vit $\mathrm{E}$ was normalized in patients subjected to coronary artery bypass graft surgery, valve surgery, or combined procedures, in which it had no effect on oxidative stress biomarkers or on postoperative clinical outcomes [117]. Moreover, in a recent study, the use of Vit $\mathrm{E}$ was able to reduce the biomarkers of oxidative stress and inflammation in a murine model of $I / R$ along with the preservation of cardiac function [101]. This has also been used in combination with Vit $C$ in a clinical trial [64] that reported an improvement in cardiac function and a decrease in the levels of oxidative stress in patients subjected to angioplasty.

Therefore, in summary, Vit E has showed a beneficial effect due to its radical scavenger activity when it is administered at the correct time and for an appropriate duration [118]. However, Miller et al. concluded that high doses ( $>400 \mathrm{IU} / \mathrm{d})$ may increase all-cause mortality [119].

\subsection{N-Acetylcysteine}

It is a compound having widely clinical use, having shown to be safe and well tolerated when administered orally [120]. Its results in cardioprotection have not been conclusive, and, at present, its mechanism of action has not been fully elucidated; however, with the passage of time, extensive evidence has been gathered that establishes Vit E as a key point, being a precursor for the synthesis of GSH and therefore an extremely important molecule for the antioxidant system. It is a compound having widely clinical use, having shown to be safe and well tolerated when administered orally [120]. Its results in cardioprotection have not been conclusive, and, at present, its mechanism of action has not been fully elucidated; however, with the passage of time, extensive evidence has been gathered that establishes Vit $\mathrm{E}$ as a key point, being a precursor for the synthesis of GSH and therefore an extremely important molecule for the antioxidant system. N-Acetylcysteine (Figure 5) is a compound having widely clinical use, having shown to be safe and well tolerated when administered orally [120]. Its results in cardioprotection have not been conclusive, and, at present, its mechanism of action has not been fully elucidated; however, with the passage of time, extensive evidence has been gathered that establishes Vit $\mathrm{E}$ as a key point, being a precursor for the synthesis of GSH and therefore an extremely important molecule for the antioxidant system. Moreover, NAC have indirect action as a metal ion chelator [121] and an ROS scavenging effect, along with the ability to inhibit NF-kB [122]. 


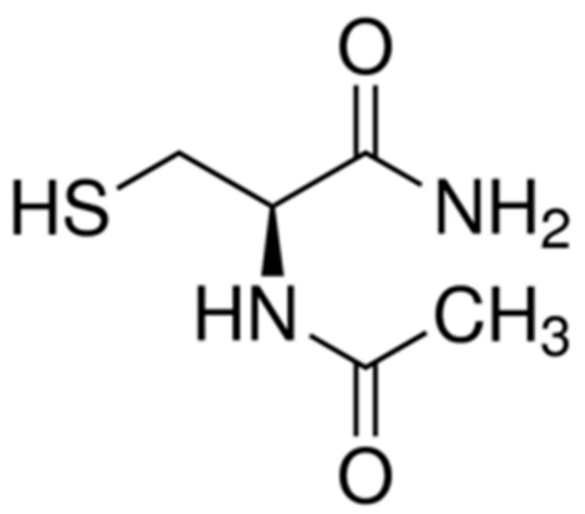

Figure 5. Molecular structure of $\mathrm{N}$-acetylcysteine.

In clinical trials, NAC has been administered to patients undergoing angioplasty, where the results in reducing MIRI have been inconclusive. In an LIPSIA-N-ACC trial, NAC infusion was used during and after reperfusion, showing insignificant effects on the size of the infarct, but a decrease of $20 \%$ in oxidative stress parameters, measured from oxidized proteins and lipoproteins [103]. In another study, where patients received NAC infusion with nitroglycerin and streptokinase, a better preservation of the left ventricular function and a decrease in oxidative stress biomarkers were obtained [104]. Nozari et al. performed a randomized, double-blind, placebo-controlled trial, wherein they administered NAC before and during reperfusion. This resulted in a significant decrease in hs-TNT levels in patients supplemented with NAC versus the placebo, along with a higher percentage of patients with TIMI 3 flow in those who received the drug [105]. However, this study did not measure infarct size or other oxidative stress biomarkers. The NACIAM study was a randomized, double-blind, placebo-controlled, multicenter trial that administered a total of $29 \mathrm{~g}$ of intravenous NAC infusion during the first $48 \mathrm{~h}$ after angioplasty in combination with nitroglycerin, showing a decrease in the infarct size, but no difference in functional parameters such as LVEF and end-systolic volumes [123]. Moreover, NAC was found to confer cardioprotection in other clinical models of I/R, such as in the study of Ozaydin et al., which was conducted as a prospective, randomized, placebo-controlled pilot study to prevent postoperative atrial fibrillation by administering NAC infusion, reporting a decreased incidence of postoperative atrial fibrillation in which adverse effects associated with NAC were found [106].

The side effects of NAC remains unclear, but so far NAC has shown no relevant adverse effects and is cheap and easily available [124,125].

\subsection{Deferoxamine}

Iron plays a fundamental role in MIRI, as an increased plasma concentration of this metal ion has been demonstrated after heart reperfusion. Ferrous iron has been described as being part of the labile iron pool which is capable of reacting with hydrogen peroxide and producing the dangerous $\cdot \mathrm{OH}$, thereby triggering extensive oxidative damage. Furthermore, in recent years, evidence has shown its importance in a new, non-apoptotic cell death pathway called ferroptosis, which has a highly inflammatory component and can spread to neighboring cells [126]. It has been described in animal models of I/R [89], in which Tang et al. demonstrated that ferroptosis occurs during reperfusion and not in ischemia in a rat heart model of I/R [127]. Therefore, the use of a chelating agent for this metal ion is relevant when it is intended to develop a therapy designed to lower MIRI. Some clinical trials have been carried out using DFO (Figure 6) during myocardial reperfusion. For example, Paraskevaidis et al. administered $4 \mathrm{~g}$ of DFO dissolved in $250 \mathrm{~mL}$ of $5 \%$ dextrose solution continuously for $8 \mathrm{~h}$ in patients undergoing coronary artery bypass grafting, obtaining in the group treated with DFO a complete suppression of the formation of ROS after surgery and a significant improvement in the LVEF, compared to the placebo group. The increase in the LVEF was observed in a much more representative way in the 
group of patients with a worse LVEF [107]. Subsequently, Chan et al. administered $500 \mathrm{mg}$ of DFO 5 to $10 \mathrm{~min}$ before PCI, followed by $50 \mathrm{mg} / \mathrm{kg}$ over $12 \mathrm{~h}$ infusion which achieved a significant decrease in serum iron and plasma $\mathrm{F}_{2}$-isoprostane levels when compared to the placebo during the first hours. However, the infarct size did not decrease significantly [108].<smiles>CC(=O)N(O)CCCCCNC(=O)CCC(=O)N(O)CCCCCNC(=O)CCC(=O)N(O)CCCCCN</smiles>

Figure 6. Molecular structure of deferoxamine mesylate.

In addition, DFO is commonly used as a treatment for iron poisoning and other pathologies as several studies have determined that acute DFO administration is safe. However, prolonged intravenous doses might cause cardiovascular, pulmonary, and auditory toxicity, as well as an increase in the risk of infection [128,129].

\subsection{Polyphenols and Other Antioxidant Compounds}

Polyphenols are compounds present in a diet, especially in fruits, vegetables, and red wine. They are classified as flavonoid, such as flavonols or anthocyanins and nonflavonoid such as stilbenes [130]. Their structure is characterized by an aromatic ring and contains one or more hydroxyl substituents and can be a simple molecule or highly polymerized compounds. Polyphenols have shown promising effects in preventing various diseases due to their ability to act as scavengers of reactive nitrogen and oxygen species and their role in improving inflammation and activating antioxidant enzymes and metal chelators [131]. Recently, research on polyphenols has been increasing due to their pharmacological characteristics. Most studies have focused on their various bioactivities, such as their antioxidant, antitumor activity, anti-inflammatory effects, and free radical scavenging [132-134]. (Figure 7). Polyphenols have shown promising effects in preventing various diseases due to their ability to act as scavengers of reactive nitrogen and oxygen species and their role in improving inflammation and activating antioxidant enzymes and metal chelators [131]. Recently, research on polyphenols has been increasing due to their pharmacological characteristics. Most studies have focused on their various bioactivities, such as their antioxidant, antitumor activity, anti-inflammatory effects, and free radical scavenging [132-134].<smiles>O=c1c(O)c(-c2ccc(O)c(O)c2)oc2cc(O)cc(O)c12</smiles>

(A)<smiles>Oc1ccc(/C=C/c2cc(O)cc(O)c2)cc1</smiles>

(B)

Figure 7. Molecular structures of two polyphenols: quercetin (A) and resveratrol (B).

There are other important properties that can be relevant, especially in the heart, to confer cardioprotection, but this effect cannot be attributed to all polyphenols, since some of them had no significant effect on the resultant damage and others displayed undesired side effects [135-137]. Nevertheless, many natural types produce positive effects 
on the cardiovascular system and are characterized by their ability to scavenge oxygenfree radicals, maintain NO concentration, inhibit an excessive immune innate response, improve endothelial function, and reverse hyperlipidemia [138].

It is known that the inflammatory response, which includes neutrophil infiltration, plays an important role in the I/R process. NLRP3 (NALP3) inflammasome, which contains proCaspase1, produces an inflammatory response by the production of IL-1. Inhibition of IL-1, as well as IL-18, reduces MIRI [114,139]. In previous studies, resveratrol, a stilbene-derived flavonol, has shown cardioprotective effects and beneficial effects against MIRI [140,141], and Dong et al. confirmed its role in inhibiting the innate immune pathway [114].

In addition, the association between polyphenols and Vit $C$ produces an antioxidant synergy, since Vit $C$ protects the flavonoids from oxidative degradation and flavonoids, in turn, act as antioxidants and iron chelators. Consistent with this view, the metal ionflavonoid complexes retain the antioxidant activities of the flavonoids and increase the free radical scavenging activities [136,142].

With regard to the use of polyphenols, care must be taken with the doses administered and the possible toxic and deleterious effects that they can cause, as in the case of C3OG, which, at the highest concentrations $(50-100 \mu \mathrm{mol} / \mathrm{L})$, does not ensure a greater effect but rather induces toxicity. Another difficulty is translating laboratory studies of polyphenols into clinical practice, given the existence of a certain inconsistency between preclinical and clinical trials, most likely dictated by the fact that metabolism and physiological concentrations were not taken into account $[130,138]$.

Moreover, despite resveratrol being one of the most studied polyphenols, there are few studies about its toxicity, and the follow-up time is short. These studies have shown that high doses have a toxic effect due to its hormetic property because resveratrol acts as a pro-oxidant molecule $[143,144]$. The effects depend on the time course of administration, dosing, study design, interactions with other drugs, and on the characteristics of the enrolled patients [144].

\section{Towards a Potential Synergistic Cardioprotection Achieved by Combined Antioxidants}

Myocardial ischemia reperfusion injury can produce extensive damage because it acts in multiple ways, acutely and chronically. Although, in recent years, there have been several studies on ischemic conditioning (pre- and post-conditioning), they have been disappointing in their clinical application [145]. Because of this, other ways to achieve cardioprotection have been studied, and a cost-effective study has established the positive economic consequences of the use of a cardioprotective therapy in patients with AMI involving endogenous cardioprotection strategies, beta-blocker therapy, or even mitochondria-targeted cardioprotection strategies $[11,145,146]$, which makes it a very striking strategy not only for its effects at the tissue level. According to Davidson et al., a multitarget cardioprotective therapy is defined as the additive or synergistic cardioprotective effects of multiple agents or interventions directed to distinct targets [11] and that, in the future, this option should be considered as a parallel treatment to the restoration of blood flow after ischemia. A combination of drugs such as Vit $C$ and Vit $E$ has been carried out in MIRI but without the expected success, as had occurred with this association in causing a significant decrease in blood pressure $[147,148]$. Other multitarget studies have been successful [145], suggesting that a combination of antioxidants and other antihypertensive drugs are useful for cardiovascular diseases [148]. In light of this, we focus on the combination of Vit $\mathrm{C}$ acting as an ROS scavenger, DFO acting on iron metabolism (reducing $\cdot \mathrm{OH}$ formation), and NAC acting as a GSH precursor (Figure 1) as a promising combined antioxidant therapy that should be evaluated in randomized clinical trials [148].

\section{Discussion}

Oxidative stress has been one of the most studied mechanisms within the pathophysiology of MIRI, and this has led to antioxidant-based therapies. Thus, to abrogate the consequences of this injury, Vit $C$ and other antioxidants have been proposed as alternatives. 
However, the achievements in human models have not been consistent with those of experimental studies. In the case of Vit C, firstly, it could be argued that there are limitations in using a dose known to lead to superoxide scavenge, as high plasma Vit $C$ concentrations generate an iron-dependent pro-oxidant effect, whereas a weak effect can be expected from low doses. In addition, there is a difficulty of comparison between studies, given the existence of a wide variability of designs present in the state of the art, which differ in the model, doses, forms of administration, and the time course of Vit $C$ administration (Table 1). In addition to the before-mentioned studies, there are a few which relate the effects of therapy with the plasma levels of the drug reached in patients, which has led to obscuring the analysis of the concentration: effect ratio. Experimental data induces us to think of a biphasic action of Vit $\mathrm{C}$, achieving a beneficial effect until intermediate concentrations, but this effect has been lost at $10 \mathrm{mmol} / \mathrm{L}$ and replaced by a pro-oxidant one.

Of note is the strength given by the beneficial functional actions that have already been previously reported in patients, both from Vit $C$ and other antioxidants. In addition, it is also important to take into consideration that the nature of the clinical model being studied requires a brief and unique exposure to block the damage caused by ROS during the first minutes of reperfusion, thus avoiding the risk of adverse events. Numerous studies have contributed to demonstrate the safety of Vit $C$ when used in wide ranges of doses, either alone or combined with other antioxidant agents. As the diversity of antioxidants offer various kinds of antioxidant mechanisms, a joint cardioprotective effect derived from the addition of the individual biological actions known to occur in the monotherapies should be expected. Finally, even though MIRI has been studied for decades, which is a highly prevalent process, given the epidemiology of acute myocardial infarction worldwide, it has not yet been possible to establish a treatment that can fully demonstrate cardioprotective efficacy, and the present study provides an underexplored opportunity for progress in this line of research.

\section{Concluding Remarks and Future Perspectives}

It is well recognized that Vit $C$ is involved in the antioxidant effect against oxidative stress related diseases as those derived from I/R events, such as AMI followed by PCI. Although considerable effort has been previously devoted to prevent the reperfusion damage by antioxidants, the results remain disappointing. This could be due to lack of accurate clinical trials, the need for a better knowledge of pharmacodynamic and pharmacokinetic properties of Vit $C$ and other antioxidants, or the required improvement of flawed study designs. Partly successful individual effects of antioxidant monotherapies have been reported in clinical studies. Nevertheless, the complexity of a pathology such as AMI followed by PCI demands a specific design of appropriate strategies aimed to abrogate the pathophysiological injurious cascade causing cell death with the aid of an association of antioxidants. Thus, we hereby propose a novel multitarget therapy based on the antioxidant and pleiotropic properties of Vit C, Vit E, or even polyphenols, and $\mathrm{NAC}$, accounting for the scavenging of reactive oxygen species and the generation of reduced glutathione. Particularly relevant is the view that iron chelation (DFO) can lead to a reinforcement of cardioprotection in mitigating the harmful $\mathrm{OH}$ generation and the occurrence of ferroptosis-induced cell death, recently recognized as a new form of cell death. The aim of this association in clinical therapeutic perspectives for humans is to achieve a synergistic protection against I/R injury, thereby diminishing the final infarct size to improve the clinical outcome of AMI patients subjected to PCI through the administration of safe, low-cost, and easily available pharmacological agents.

Author Contributions: R.R.: Hypothesis design, fund raising; L.S.: Scientific study rationale; J.C.P.: Pharmacological bases; R.A.: Clinical effects of antioxidants and DFO; C.R.: Factors determining de infarct size in AMI + PCI; Á.P.: Studies about PCI; A.G.: Statistical value of studies; E.P.: Biochemical events at the cell level; C.R.-S.: Analysis of published articles; J.L.-M.: Studies about cell death and ferroptosis. All authors have read and agreed to the published version of the manuscript. 
Funding: This study was supported by the Agencia Nacional de Investigación y desarrollo (ANID), Fondo Nacional de Desarrollo Científico, Tecnológico y de Innovación Tecnológica, (FONDECYT), grant number 1211850 .

Institutional Review Board Statement: The study is being conducted according to the guidelines of the Declaration of Helsinki, and approved by the Ethics Committee of Research in Human Beings of the Faculty of Medicine, University of Chile (protocol code 095-2020, file number 186), approved on 23 March 2021

Informed Consent Statement: Written informed consent will be obtained from the patients to publish the results.

Data Availability Statement: Not applicable.

Conflicts of Interest: The authors declare no conflict of interest.

\section{Abbreviations}

AMI

AREs

ATP

$\mathrm{BH} 4$

C3OG

CAT

cTnI

cTnT

CK-MB

DFO

DHA

FRAP

Gclc

Gclm

GPXs

GR

GRXs

GSH

hs-CRP

HO-1

$\mathrm{H}_{2} \mathrm{O}_{2}$

$\mathrm{I} / \mathrm{R}$

IVRT

Keap1

LDH

LV

LVEF

LVFS

MDA

MIRI

MPO

MPTP

NAC

NADPH

NALP3

NF-KB

$\mathrm{NO}$.

NOO

NOX

Nrf2

${ }^{1} \mathrm{O}_{2}$
Acute myocardial infarction

Antioxidant response elements

Adenosine triphosphate

Tetrahydrobiopterin

cyanidin-3-O-glucoside

catalase

troponin I

cardiac troponin $\mathrm{T}$

creatinine phosphokinase MB isoenzyme

deferoxamine

dehydroascorbic acid

ferric reducing ability of plasma

Glutamate-Cysteine Ligase Catalytic Subunit

Glutamate-Cysteine Ligase Modifier Subunit

glutathione peroxidases

glutathione reductase

glutaredoxins

reduced glutathione

high-sensitivity C-reactive protein

heme oxygenase-1

hydrogen peroxide

ischemia/reperfusion

$\mathrm{LV}$ isovolumic relaxation time

Kelch-like ECH-associated protein 1

lactate dehydrogenase

left ventricle

LV ejection fraction

LV fractional shortening

malondialdehyde

myocardial ischemia reperfusion injury

myeloperoxidase

mitochondrial permeability transition pore

$\mathrm{N}$-acetylcysteine

nicotinamide adenine dinucleotide phosphate

NLRP3 inflammasome

nuclear factor kappa-light-chain-enhancer of activated B cells

nitric oxide radical

nitrogen dioxide radical

NADPH oxidase

nuclear factor-erythroid 2-related factor 2

oxygen singlet 


$\begin{array}{ll}\mathrm{O}_{2} \cdot- & \text { superoxide anion radical } \\ \mathrm{OH} & \text { hydrogen peroxide } \\ \text { ONOO- } & \text { peroxynitrite anion } \\ \text { P3OG } & \text { pelargonidin-3-O-glucoside } \\ \text { PCI } & \text { percutaneous coronary intervention } \\ \text { PRXs } & \text { peroxiredoxins } \\ \text { ROS } & \text { reactive oxygen species } \\ \text { SODs } & \text { superoxide dismutases } \\ \text { sCD40L } & \text { soluble CD40 ligand } \\ \text { sNOX2-dp } & \text { soluble NOX2-derived peptide } \\ \text { SVCT1 } & \text { sodium-ascorbate co-transporters 1 } \\ \text { SVCT2 } & \text { sodium-ascorbate co-transporters 2 } \\ \text { TNF } \alpha & \text { tumor necrosis factor alpha } \\ \text { TRXs } & \text { thioredoxins } \\ \text { TxB2 } & \text { Thromboxane B2 } \\ \text { un-eNOS } & \text { uncoupled endothelial nitric oxide synthase } \\ \text { Vit C } & \text { vitamin C } \\ \text { Vit E } & \text { vitamin E } \\ \text { XO } & \text { xanthine oxidase }\end{array}$

\section{References}

1. WHO. WHO Reveals Leading Causes of Death and Disability Worldwide: 2000-2019. Available online: https://www.who.int/ news/item/09-12-2020-who-reveals-leading-causes-of-death-and-disability-worldwide-2000-2019 (accessed on 17 May 2021).

2. WHO. Cardiovascular Diseases. Available online: https://www.who.int/health-topics/cardiovascular-diseases/\#tab=tab_1 (accessed on 17 May 2021).

3. White, H.D.; Chew, D.P. Acute myocardial infarction. Lancet 2008, 372, 570-584. [CrossRef]

4. Ahmad, M.; Mehta, P.; Reddivari, A.K.R.; Mungee, S. Percutaneous Coronary Intervention; StatPearls Publishing: Treasure Island, FL, USA, 2021.

5. Massalha, S.; Luria, L.; Kerner, A.; Roguin, A.; Abergel, E.; Hammerman, H.; Boulos, M.; Dragu, R.; Kapeliovich, M.R.; Beyar, R.; et al. Heart failure in patients with diabetes undergoing primary percutaneous coronary intervention. Eur. Heart J. Acute Cardiovasc. Care 2016, 5, 455-462. [CrossRef]

6. Yellon, D.M.; Hausenloy, D.J. Myocardial Reperfusion Injury. N. Engl. J. Med. 2007, 357, 1121-1135. [CrossRef]

7. $\quad$ Berretta, M.; Quagliariello, V.; Maurea, N.; Di Francia, R.; Sharifi, S.; Facchini, G.; Rinaldi, L.; Piezzo, M.; Ceccarelli, M.; Nunnari, G.; et al. Multiple effects of ascorbic acid against chronic diseases: Updated evidence from preclinical and clinical studies. Antioxidants 2020, 9, 1182. [CrossRef]

8. Lykkesfeldt, J.; Tveden-Nyborg, P. The pharmacokinetics of vitamin C. Nutrients 2019, 11, 2412. [CrossRef] [PubMed]

9. Khan, S.A.; Bhattacharjee, S.; Ghani, M.O.A.; Walden, R.; Chen, Q.M. Vitamin c for cardiac protection during percutaneous coronary intervention: A systematic review of randomized controlled trials. Nutrients 2020, 12, 2199. [CrossRef] [PubMed]

10. Nakamura, T.; Naguro, I.; Ichijo, H. Iron homeostasis and iron-regulated ROS in cell death, senescence and human diseases. Biochim. Biophys. Acta (BBA) - Gen. Subj. 2019, 1863, 1398-1409. [CrossRef]

11. Davidson, S.M.; Ferdinandy, P.; Andreadou, I.; Bøtker, H.E.; Heusch, G.; Ibáñez, B.; Ovize, M.; Schulz, R.; Yellon, D.M.; Hausenloy, D.J.; et al. Multitarget Strategies to Reduce Myocardial Ischemia/Reperfusion Injury: JACC Review Topic of the Week. J. Am. Coll. Cardiol. 2019, 73, 89-99. [CrossRef] [PubMed]

12. Rodrigo, R. Oxidative Stress and Antioxidants: Their Role in Human Disease; Rodrigo, R., Ed.; Nova Science Publishers: Hauppauge, NY, USA, 2009; ISBN 978-1-60741-554-1.

13. Quinlan, C.L.; Goncalves, R.L.S.; Hey-Mogensen, M.; Yadava, N.; Bunik, V.I.; Brand, M.D. The 2-Oxoacid Dehydrogenase Complexes in Mitochondria Can Produce Superoxide/Hydrogen Peroxide at Much Higher Rates Than Complex I*. J. Biol. Chem. 2014, 289, 8312-8325. [CrossRef] [PubMed]

14. Rodrigo, R.; Prieto, J.C.; Castillo, R. Cardioprotection against ischaemia/reperfusion by vitamins C and E plus n-3 fatty acids: Molecular mechanisms and potential clinic applications. Clin. Sci. 2013, 124, 1-15. [CrossRef] [PubMed]

15. Raedschelders, K.; Ansley, D.M.; Chen, D.D.Y. The cellular and molecular origin of reactive oxygen species generation during myocardial ischemia and reperfusion. Pharmacol. Ther. 2012, 133, 230-255. [CrossRef]

16. Gasparetto, C.; Malinverno, A.; Culacciati, D.; Gritti, D.; Prosperini, P.G.; Specchia, G.; Ricevuti, G. Antioxidant vitamins reduce oxidative stress and ventricular remodeling in patients with acute myocardial infarction. Int. J. Immunopathol. Pharmacol. 2005, 18, 487-496. [CrossRef] [PubMed]

17. Hybertson, B.M.; Gao, B.; Bose, S.K.; McCord, J.M. Oxidative stress in health and disease: The therapeutic potential of Nrf2 activation. Mol. Asp. Med. 2011, 32, 234-246. [CrossRef]

18. Shen, Y.; Liu, X.; Shi, J.; Wu, X. Involvement of Nrf2 in myocardial ischemia and reperfusion injury. Int. J. Biol. Macromol. 2019, 125, 496-502. [CrossRef] [PubMed] 
19. Xu, B.; Zhang, J.; Strom, J.; Lee, S.; Chen, Q.M. Myocardial ischemic reperfusion induces de novo Nrf2 protein translation. Biochim. Biophys. Acta (BBA)- Mol. Basis Dis. 2014, 1842, 1638-1647. [CrossRef]

20. Zhang, X.; Xiao, Z.; Yao, J.; Zhao, G.; Fa, X.; Niu, J. Participation of protein kinase C in the activation of Nrf2 signaling by ischemic preconditioning in the isolated rabbit heart. Mol. Cell. Biochem. 2013, 372, 169-179. [CrossRef]

21. Valko, M.; Leibfritz, D.; Moncol, J.; Cronin, M.T.D.; Mazur, M.; Telser, J. Free radicals and antioxidants in normal physiological functions and human disease. Int. J. Biochem. Cell Biol. 2007, 39, 44-84. [CrossRef] [PubMed]

22. Sies, H. Hydrogen peroxide as a central redox signaling molecule in physiological oxidative stress: Oxidative eustress. Redox Biol. 2017, 11, 613-619. [CrossRef] [PubMed]

23. Ferrari, R.; Balla, C.; Malagù, M.; Guardigli, G.; Morciano, G.; Bertini, M.; Biscaglia, S.; Campo, G. Reperfusion damage-A story of success, failure, and hope-. Circ. J. 2017, 81, 131-141. [CrossRef] [PubMed]

24. Ambrosio, G.; Weisfeldt, M.L.; Jacobus, W.E.; Flaherty, J.T.; Hopkins, J. Evidence for a reversible oxygen radical-mediated component of reperfusion injury: Reduction by recombinant human superoxide dismutase administered at the time of reflow EXPERIMENTAL and clinical studies have indicated From the Department of Medicine, Division of Cardiology, The that timely reperfusion of ischemic myocardium can. Lab. Investig. Myocard. Reperfus. Circ. 1987, 75, 282-291.

25. Neely, J.R.; Grotyohann, L.W. Role of glycolytic products in damage to ischemic myocardium. Dissociation of adenosine triphosphate levels and recovery of function of reperfused ischemic hearts. Circ. Res. 1984, 55, 816-824. [CrossRef] [PubMed]

26. Orchard, C.; Kentish, J. Effects of changes of $\mathrm{pH}$ on the contractile function of cardiac muscle. Am. J. Physiol. 1990, 258, C967-C981. [CrossRef]

27. Avkiran, M.; Marber, M. Na(+)/H(+) exchange inhibitors for cardioprotective therapy: Progress, problems and prospects. J. Am. Coll. Cardiol. 2002, 39, 747-753. [CrossRef]

28. Rossi, A.E.; Dirksen, R.T. Sarcoplasmic reticulum: The dynamic calcium governor of muscle. Muscle Nerve 2006, 33, 715-731. [CrossRef]

29. Bernardi, P.; Vassanelli, S.; Veronese, P.; Colonna, R.; Szabo, I.; Zoratti, M. Modulation of the mitochondrial permeability transition pore. Effect of protons and divalent cations. J. Biol. Chem. 1992, 267, 2934-2939. [CrossRef]

30. Zweier, J.L.; Flaherty, J.T.; Weisfeldt, M.L. Direct measurement of free radical generation following reperfusion of ischemic myocardium. Proc. Natl. Acad. Sci. USA 1987, 84, 1404-1407. [CrossRef]

31. Braunersreuther, V.; Jaquet, V. Reactive oxygen species in myocardial reperfusion injury: From physiopathology to therapeutic approaches. Curr. Pharm. Biotechnol. 2012, 13, 97-114. [CrossRef] [PubMed]

32. González-Montero, J.; Brito, R.; Gajardo, A.I.; Rodrigo, R. Myocardial reperfusion injury and oxidative stress: Therapeutic opportunities. World J. Cardiol. 2018, 10, 74. [CrossRef] [PubMed]

33. Granger, D.N.; Kvietys, P.R. Reperfusion injury and reactive oxygen species: The evolution of a concept. Redox Biol. 2015, 6, 524-551. [CrossRef] [PubMed]

34. Berenshtein, E.; Vaisman, B.; Goldberg-Langerman, C.; Kitrossky, N.; Konijn, A.M.; Chevion, M. Roles of ferritin and iron in ischemic preconditioning of the heart. Mol. Cell. Biochem. 2002, 234, 283-292. [CrossRef] [PubMed]

35. Tang, W.H.; Wu, S.; Wong, T.M.; Chung, S.K.; Chung, S.S.M. Polyol pathway mediates iron-induced oxidative injury in ischemicreperfused rat heart. Free Radic. Biol. Med. 2008, 45, 602-610. [CrossRef]

36. Carrick, D.; Haig, C.; Ahmed, N.; McEntegart, M.; Petrie, M.C.; Eteiba, H.; Hood, S.; Watkins, S.; Lindsay, M.M.; Davie, A.; et al. Myocardial hemorrhage after acute reperfused ST-segment-elevation myocardial infarction: Relation to microvascular obstruction and prognostic significance. Circ. Cardiovasc. Imaging 2016, 9, e004148. [CrossRef]

37. Vernis, L.; El Banna, N.; Baille, D.; Hatem, E.; Heneman, A.; Huang, M.E. Fe-S Clusters Emerging as Targets of Therapeutic Drugs. Oxid. Med. Cell. Longev. 2017, 2017, 3647657. [CrossRef]

38. Fang, X.; Cai, Z.; Wang, H.; Han, D.; Cheng, Q.; Zhang, P.; Gao, F.; Yu, Y.; Song, Z.; Wu, Q.; et al. Loss of Cardiac Ferritin H Facilitates Cardiomyopathy via Slc7a11-Mediated Ferroptosis. Circ. Res. 2020, 127, 486-501. [CrossRef] [PubMed]

39. Lillo-Moya, J.; Rojas-Solé, C.; Muñoz-Salamanca, D.; Panieri, E.; Saso, L.; Rodrigo, R. Targeting ferroptosis against ischemia/reperfusion cardiac injury. Antioxidants 2021, 10, 667. [CrossRef] [PubMed]

40. Griffiths, E.J.; Halestrap, A.P. Mitochondrial non-specific pores remain closed during cardiac ischaemia, but open upon reperfusion. Biochem. J. 1995, 307, 93. [CrossRef]

41. Kim, J.; Jin, Y.; Lemasters, J. Reactive oxygen species, but not $\mathrm{Ca}^{2+}$ overloading, trigger $\mathrm{pH}$ - and mitochondrial permeability transition-dependent death of adult rat myocytes after ischemia-reperfusion. Am. J. Physiol. Heart Circ. Physiol. 2006, 290, H2024-H2034. [CrossRef] [PubMed]

42. Seidlmayer, L.; Juettner, W.; Kettlewell, S.; Pavlov, E.; Blatter, L.; Dedkova, E. Distinct mPTP activation mechanisms in ischaemiareperfusion: Contributions of $\mathrm{Ca}^{2+}$, ROS, $\mathrm{pH}$, and inorganic polyphosphate. Cardiovasc. Res. 2015, 106, 237-248. [CrossRef]

43. Kitakaze, M.; Takashima, S.; Funaya, H.; Minamino, T.; Node, K.; Shinozaki, Y.; Mori, H.; Hori, M. Temporary acidosis during reperfusion limits myocardial infarct size in dogs. Am. J. Physiol. 1997, 272, H2071-H2078. [CrossRef]

44. Baines, C.P.; Molkentin, J.D. Adenine nucleotide translocase-1 induces cardiomyocyte death through upregulation of the pro-apoptotic protein Bax. J. Mol. Cell. Cardiol. 2009, 46, 969-977. [CrossRef] [PubMed]

45. Bernardi, P. The mitochondrial permeability transition pore: A mystery solved? Front. Physiol. 2013, 4, 95. [CrossRef]

46. Hausenloy, D.J.; Maddock, H.; Baxter, G.; Yellon, D.M. Inhibiting mitochondrial permeability transition pore opening: A new paradigm for myocardial preconditioning? Cardiovasc. Res. 2002, 55, 534-543. [CrossRef] 
47. Hausenloy, D.J.; Duchen, M.; Yellon, D.M. Inhibiting mitochondrial permeability transition pore opening at reperfusion protects against ischaemia-reperfusion injury. Cardiovasc. Res. 2003, 60, 617-625. [CrossRef]

48. Argaud, L.; Gateau-Roesch, O.; Muntean, D.; Chalabreysse, L.; Loufouat, J.; Robert, D.; Ovize, M. Specific inhibition of the mitochondrial permeability transition prevents lethal reperfusion injury. J. Mol. Cell. Cardiol. 2005, 38, 367-374. [CrossRef] [PubMed]

49. Skyschally, A.; Schulz, R.; Heusch, G. Cyclosporine A at reperfusion reduces infarct size in pigs. Cardiovasc. Drugs Ther. 2010, 24, 85-87. [CrossRef]

50. Hausenloy, D.J.; Yellon, D.M. Myocardial ischemia-reperfusion injury: A neglected therapeutic target. J. Clin. Investig. 2013, 123, 92-100. [CrossRef] [PubMed]

51. Vinten-Johansen, J. Involvement of neutrophils in the pathogenesis of lethal myocardial reperfusion injury. Cardiovasc. Res. 2004, 61, 481-497. [CrossRef]

52. Parra, P.; Rodrigo, R. Novel Antioxidant Therapy against Myocardial Ischemia-Reperfusion Injury during Percutaneous Coronary Angioplasty. In Free Radicals and Diseases; Ahmad, R., Ed.; InTech: London, UK, 2016.

53. Fan, H.; Sun, B.; Gu, Q.; Lafond-Walker, A.; Cao, S.; Becker, L. Oxygen radicals trigger activation of NF-kappaB and AP-1 and upregulation of ICAM-1 in reperfused canine heart. Am. J. Physiol. Heart Circ. Physiol. 2002, 282, H1778-H1786. [CrossRef]

54. Bowie, A.; O'Neill, L. Oxidative stress and nuclear factor-kappaB activation: A reassessment of the evidence in the light of recent discoveries. Biochem. Pharmacol. 2000, 59, 13-23. [CrossRef]

55. Chandrasekar, B.; Freeman, G. Induction of nuclear factor kappaB and activation protein 1 in postischemic myocardium. FEBS Lett. 1997, 401, 30-34. [CrossRef]

56. Li, W.; Feng, G.; Gauthier, J.M.; Lokshina, I.; Higashikubo, R.; Evans, S.; Liu, X.; Hassan, A.; Tanaka, S.; Cicka, M.; et al. Ferroptotic cell death and TLR4/Trif signaling initiate neutrophil recruitment after heart transplantation. J. Clin. Investig. 2019, $129,2293$. [CrossRef] [PubMed]

57. Rivas, C.; Zúñiga, F.; Salas-Burgos, A.; Mardones, L.; Ormazabal, V.; Vera, J. Vitamin C transporters. J. Physiol. Biochem. 2008, 64, 357-375. [CrossRef] [PubMed]

58. Grover-McKay, M.; Walsh, S.; Thompson, S. Glucose transporter 3 (GLUT3) protein is present in human myocardium. Biochim. Biophys. Acta 1999, 1416, 145-154. [CrossRef]

59. Spoelstra-de Man, A.M.E.; Elbers, P.W.G.; Oudemans-van Straaten, H.M. Making sense of early high-dose intravenous vitamin C in ischemia/reperfusion injury. Annu. Update Intensive Care Emerg. Med. 2018, 22, 125-139. [CrossRef]

60. Virdis, A.; Colucci, R.; Fornai, M.; Polini, A.; Daghini, E.; Duranti, E.; Ghisu, N.; Versari, D.; Dardano, A.; Blandizzi, C.; et al. Inducible nitric oxide synthase is involved in endothelial dysfunction of mesenteric small arteries from hypothyroid rats. Endocrinology 2009, 150, 1033-1042. [CrossRef]

61. Taddei, S.; Virdis, A.; Ghiadoni, L.; Magagna, A.; Salvetti, A. Vitamin C improves endothelium-dependent vasodilation by restoring nitric oxide activity in essential hypertension. Circulation 1998, 97, 2222-2229. [CrossRef]

62. Schneider, M.; Delles, C.; Schmidt, B.; Oehmer, S.; Schwarz, T.; Schmieder, R.; John, S. Superoxide scavenging effects of $\mathrm{N}$-acetylcysteine and vitamin $\mathrm{C}$ in subjects with essential hypertension. Am. J. Hypertens. 2005, 18, 1111-1117. [CrossRef]

63. Bhakuni, P.; Chandra, M.; Misra, M. Effect of ascorbic acid supplementation on certain oxidative stress parameters in the post reperfusion patients of myocardial infarction. Mol. Cell. Biochem. 2006, 290, 153-158. [CrossRef]

64. Valls, N.; Gormaz, J.G.; Aguayo, R.; González, J.; Brito, R.; Hasson, D.; Libuy, M.; Ramos, C.; Carrasco, R.; Prieto, J.C.; et al. Amelioration of persistent left ventricular function impairment through increased plasma ascorbate levels following myocardial infarction. Redox Rep. 2016, 21, 75-83. [CrossRef]

65. Basili, S.; Tanzilli, G.; Mangieri, E.; Raparelli, V.; Di Santo, S.; Pignatelli, P.; Violi, F. Intravenous Ascorbic Acid Infusion Improves Myocardial Perfusion Grade During Elective Percutaneous Coronary Intervention: Relationship With Oxidative Stress Markers. JACC Cardiovasc. Interv. 2010, 3, 221-229. [CrossRef]

66. Pignatelli, P.; Tanzilli, G.; Carnevale, R.; Di Santo, S.; Loffredo, L.; Celestini, A.; Proietti, M.; Tovaglia, P.; Mangieri, E.; Basili, S.; et al. Ascorbic Acid Infusion Blunts CD40L Upregulation in Patients Undergoing Coronary Stent. Cardiovasc. Ther. 2011, 29, 385-394. [CrossRef] [PubMed]

67. Wang, Z.J.; Hu, W.K.; Liu, Y.Y.; Shi, D.M.; Cheng, W.J.; Guo, Y.H.; Yang, Q.; Zhao, Y.X.; Zhou, Y.J. The Effect of Intravenous Vitamin C Infusion on Periprocedural Myocardial Injury for Patients Undergoing Elective Percutaneous Coronary Intervention. Can. J. Cardiol. 2014, 30, 96-101. [CrossRef]

68. Guan, W.; Osanai, T.; Kamada, T.; Ishizaka, H.; Hanada, H.; Okumura, K. Time Course of Free Radical Production After Primary Coronary Angioplasty for Acute Myocardial Infarction and the Effect of Vitamin C. Jpn. Circ. J. 1999, 63, 924-928. [CrossRef] [PubMed]

69. Ramos, C.; Brito, R.; González-Montero, J.; Valls, N.; Gormaz, J.G.; Prieto, J.C.; Aguayo, R.; Puentes, Á.; Noriega, V.; Pereira, G.; et al. Effects of a novel ascorbate-based protocol on infarct size and ventricle function in acute myocardial infarction patients undergoing percutaneous coronary angioplasty. Arch. Med. Sci. 2017, 13, 558. [CrossRef]

70. Akolkar, G.; da Silva Dias, D.; Ayyappan, P.; Bagchi, A.K.; Jassal, D.; Salemi, V.; Irigoyen, M.; De Angelis, K.; Singal, P. Vitamin C mitigates oxidative/nitrosative stress and inflammation in doxorubicin-induced cardiomyopathy. Am. J. Physiol. Heart Circ. Physiol. 2017, 313, 795-809. [CrossRef] [PubMed] 
71. Solaro, R.; Arteaga, G. Heart failure, ischemia/reperfusion injury and cardiac troponin. Adv. Exp. Med. Biol. 2007, 592, 191-200. [CrossRef]

72. Thygesen, K.; Alpert, J.; Jaffe, A.; Chaitman, B.; Bax, J.; Morrow, D.; White, H. Fourth Universal Definition of Myocardial Infarction (2018). J. Am. Coll. Cardiol. 2018, 72, 2231-2264. [CrossRef]

73. Shafaei-Bajestani, N.; Talasaz, A.; Salarifar, M.; Pourhosseini, H.; Sadri, F.; Jalali, A. Potential Role of Vitamin C Intracoronary Administration in Preventing Cardiac Injury After Primary Percutaneous Coronary Intervention in Patients with ST-Elevation Myocardial Infarction. J. Res. Pharm. Pract. 2019, 8, 75-82. [CrossRef]

74. Jackson, T.; Xu, A.; Vita, J.; Keaney, J. Ascorbate prevents the interaction of superoxide and nitric oxide only at very high physiological concentrations. Circ. Res. 1998, 83, 916-922. [CrossRef]

75. Rodrigo, R.; Libuy, M.; Feliú, F.; Hasson, D. Molecular basis of cardioprotective effect of antioxidant vitamins in myocardial infarction. Biomed Res. Int. 2013, 2013, 437613. [CrossRef]

76. Ulker, S.; McKeown, P.; Bayraktutan, U. Vitamins reverse endothelial dysfunction through regulation of eNOS and NAD(P)H oxidase activities. Hypertension 2003, 41, 534-539. [CrossRef] [PubMed]

77. Cárcamo, J.; Pedraza, A.; Bórquez-Ojeda, O.; Golde, D. Vitamin C suppresses TNF alpha-induced NF kappa B activation by inhibiting I kappa B alpha phosphorylation. Biochemistry 2002, 41, 12995-13002. [CrossRef] [PubMed]

78. Newaz, M.A.; Yousefipour, Z.; Nawal, N.N.A. Modulation of nitric oxide synthase activity in brain, liver, and blood vessels of spontaneously hypertensive rats by ascorbic acid: Protection from free radical injury. Clin. Exp. Hypertens. 2005, 27, 497-508. [CrossRef]

79. Yang, Z.; Ming, X.-F. Recent Advances in Understanding Endothelial Dysfunction in Atherosclerosis. Clin. Med. Res. 2006, 4, 53. [CrossRef] [PubMed]

80. Packer, J.; Slater, T.; Willson, R. Direct observation of a free radical interaction between vitamin E and vitamin C. Nature 1979, 278, 737-738. [CrossRef]

81. Niki, E.; Noguchi, N.; Tsuchihashi, H.; Gotoh, N. Interaction among vitamin C, vitamin E, and beta-carotene. Am. J. Clin. Nutr. 1995, 62, 1322-1326. [CrossRef] [PubMed]

82. May, J.; Qu, Z.; Mendiratta, S. Protection and recycling of alpha-tocopherol in human erythrocytes by intracellular ascorbic acid. Arch. Biochem. Biophys. 1998, 349, 281-289. [CrossRef]

83. Burton, G.W.; Ingold, K.U. Autoxidation of biological molecules. 1. Antioxidant activity of vitamin E and related chain-breaking phenolic antioxidants in vitro. J. Am. Chem. Soc. 1981, 103, 6472-6477. [CrossRef]

84. Graumlich, J.; Ludden, T.; Conry-Cantilena, C.; Cantilena, L.; Wang, Y.; Levine, M. Pharmacokinetic model of ascorbic acid in healthy male volunteers during depletion and repletion. Pharm. Res. 1997, 14, 1133-1139. [CrossRef]

85. Padayatty, S.; Sun, A.; Chen, Q.; Espey, M.; Drisko, J.; Levine, M. Vitamin C: Intravenous use by complementary and alternative medicine practitioners and adverse effects. PLoS ONE 2010, 5, e11414. [CrossRef]

86. Buettner, G.R.; Jurkiewicz, B.A. Catalytic metals, ascorbate and free radicals: Combinations to avoid. Radiat. Res. 1996, 145, 532-541. [CrossRef] [PubMed]

87. May, J.; Qu, Z.; Whitesell, R.; Cobb, C. Ascorbate recycling in human erythrocytes: Role of GSH in reducing dehydroascorbate. Free Radic. Biol. Med. 1996, 20, 543-551. [CrossRef]

88. Mendiratta, S.; Qu, Z.; May, J. Enzyme-dependent ascorbate recycling in human erythrocytes: Role of thioredoxin reductase. Free Radic. Biol. Med. 1998, 25, 221-228. [CrossRef]

89. Fang, X.; Wang, H.; Han, D.; Xie, E.; Yang, X.; Wei, J.; Gu, S.; Gao, F.; Zhu, N.; Yin, X.; et al. Ferroptosis as a target for protection against cardiomyopathy. Proc. Natl. Acad. Sci. USA 2019, 116, 2672-2680. [CrossRef]

90. Shen, S.C.; He, F.; Cheng, C.; Xu, B.L.; Sheng, J.L. Uric acid aggravates myocardial ischemia-reperfusion injury via ROS/NLRP3 pyroptosis pathway. Biomed. Pharmacother. 2021, 133, 110990. [CrossRef] [PubMed]

91. Nishinaka, Y.; Sugiyama, S.; Yokota, M.; Saito, H.; Ozawa, T. The effects of a high dose of ascorbate on ischemia-reperfusioninduced mitochondrial dysfunction in canine hearts. Heart Vessels 1992, 7, 18-23. [CrossRef]

92. Klein, H.H.; Pich, S.; Lindert, S.; Nebendahl, K.; Niedmann, P.; Kreuzer, H. Combined treatment with vitamins E and C in experimental myocardial infarction in pigs. Am. Heart J. 1989, 118, 667-673. [CrossRef]

93. Gao, F.; Yao, C.L.; Gao, E.; Mo, Q.Z.; Yan, W.L.; McLaughlin, R.; Lopez, B.L.; Christopher, T.A.; Ma, X.L. Enhancement of glutathione cardioprotection by ascorbic acid in myocardial reperfusion injury. J. Pharmacol. Exp. Ther. 2002, 301, 543-550. [CrossRef]

94. Chatziathanasiou, G.N.; Nikas, D.N.; Katsouras, C.S.; Kazakos, N.D.; Bouba, V.; Vougiouklakis, T.; Naka, K.K.; Michalis, L.K. Combined intravenous treatment with ascorbic acid and desferrioxamine to reduce myocardial reperfusion injury in an experimental model resembling the clinical setting of primary PCI. Hell. J. Cardiol. 2012, 53, 195-204.

95. Nikas, D.N.; Chatziathanasiou, G.; Kotsia, A.; Papamichael, N.; Thomas, C.; Papafaklis, M.; Naka, K.K.; Kazakos, N.; Milionis, H.J.; Vakalis, K.; et al. Effect of intravenous administration of antioxidants alone and in combination on myocardial reperfusion injury in an experimental pig model. Curr. Ther. Res. - Clin. Exp. 2008, 69, 423-439. [CrossRef]

96. Hao, J.; Li, W.W.; Du, H.; Zhao, Z.F.; Liu, F.; Lu, J.C.; Yang, X.C.; Cui, W. Role of Vitamin C in cardioprotection of ischemia/reperfusion injury by activation of mitochondrial katp channel. Chem. Pharm. Bull. 2016, 64, 548-557. [CrossRef] 
97. Parra-Flores, P.; Riquelme, J.A.; Valenzuela-Bustamante, P.; Leiva-Navarrete, S.; Vivar, R.; Cayupi-Vivanco, J.; Castro, E.; Espinoza-Pérez, C.; Ruz-Cortés, F.; Pedrozo, Z.; et al. The association of ascorbic acid, deferoxamine and N-acetylcysteine improves cardiac fibroblast viability and cellular function associated with tissue repair damaged by simulated ischemia/reperfusion. Antioxidants 2019, 8, 614. [CrossRef]

98. Dhar-Mascareño, M.; Cárcamo, J.M.; Golde, D.W. Hypoxia-reoxygenation-induced mitochondrial damage and apoptosis in human endothelial cells are inhibited by vitamin C. Free Radic. Biol. Med. 2005, 38, 1311-1322. [CrossRef]

99. Watanabe, M.; Okada, T. Langendorff Perfusion Method as an Ex Vivo Model to Evaluate Heart Function in Rats. Methods Mol. Biol. 2018, 1816, 107-116. [CrossRef] [PubMed]

100. Halapas, A.; Papalois, A.; Stauropoulou, A.; Philippou, A.; Pissimissis, N.; Chatzigeorgiou, A.; Kamper, E.; Koutsilieris, M. In vivo models for heart failure research. In Vivo 2008, 22, 767-780.

101. Wallert, M.; Ziegler, M.; Wang, X.; Maluenda, A.; Xu, X.; Yap, M.L.; Witt, R.; Giles, C.; Kluge, S.; Hortmann, M.; et al. $\alpha$-Tocopherol preserves cardiac function by reducing oxidative stress and inflammation in ischemia/reperfusion injury. Redox Biol. 2019, 26, 101292. [CrossRef] [PubMed]

102. Chen, Y.; Yin, C.; Yang, Y.; Fan, Z.; Shang, J.; Tan, W. Inhibition of rapid delayed rectifier potassium current (I Kr) by ischemia/reperfusion and its recovery by vitamin E in ventricular myocytes. J. Electrocardiol. 2017, 50, 437-443. [CrossRef] [PubMed]

103. Thiele, H.; Hildebrand, L.; Schirdewahn, C.; Eitel, I.; Adams, V.; Fuernau, G.; Erbs, S.; Linke, A.; Diederich, K.W.; Nowak, M.; et al. Impact of High-Dose N-Acetylcysteine Versus Placebo on Contrast-Induced Nephropathy and Myocardial Reperfusion Injury in Unselected Patients With ST-Segment Elevation Myocardial Infarction Undergoing Primary Percutaneous Coronary Intervention: The LIPSIA-. J. Am. Coll. Cardiol. 2010, 55, 2201-2209. [CrossRef]

104. Arstall, M.A.; Yang, J.; Stafford, I.; Betts, W.H.; Horowitz, J.D. N-Acetylcysteine in Combination With Nitroglycerin and Streptokinase for the Treatment of Evolving Acute Myocardial Infarction. Circulation 1995, 92, 2855-2862. [CrossRef] [PubMed]

105. Nozari, Y.; Eshraghi, A.; Talasaz, A.H.; Bahremand, M.; Salamzadeh, J.; Salarifar, M.; Pourhosseini, H.; Jalali, A.; Mortazavi, S.H. Protection from Reperfusion Injury with Intracoronary N -Acetylcysteine in Patients with STEMI Undergoing Primary Percutaneous Coronary Intervention in a Cardiac Tertiary Center. Am. J. Cardiovasc. Drugs 2018, 18, 213-221. [CrossRef]

106. Ozaydin, M.; Peker, O.; Erdogan, D.; Kapan, S.; Turker, Y.; Varol, E.; Ozguner, F.; Dogan, A.; Ibrisim, E. N-acetylcysteine for the prevention of postoperative atrial fibrillation: A prospective, randomized, placebo-controlled pilot study. Eur. Heart J. 2008, 29, 625-631. [CrossRef] [PubMed]

107. Paraskevaidis, I.A.; Iliodromitis, E.K.; Vlahakos, D.; Tsiapras, D.P.; Nikolaidis, A.; Marathias, A.; Michalis, A.; Kremastinos, D.T. Deferoxamine infusion during coronary artery bypass grafting ameliorates lipid peroxidation and protects the myocardium against reperfusion injury: Immediate and long-term significance. Eur. Heart J. 2005, 26, 263-270. [CrossRef] [PubMed]

108. Chan, W.; Taylor, A.J.; Ellims, A.H.; Lefkovits, L.; Wong, C.; Kingwell, B.A.; Natoli, A.; Croft, K.D.; Mori, T.; Kaye, D.M.; et al. Effect of iron chelation on myocardial infarct size and oxidative stress in ST-elevation-myocardial infarction. Circ. Cardiovasc. Interv. 2012, 5, 270-278. [CrossRef] [PubMed]

109. Sakanashi, Y.; Oyama, K.; Matsui, H.; Oyama, T.; Oyama, T.; Nishimura, Y.; Sakai, H.; Oyama, Y. Possible use of quercetin, an antioxidant, for protection of cells suffering from overload of intracellular $\mathrm{Ca}^{2+}$ : A model experiment. Life Sci. 2008, 83, 164-169. [CrossRef] [PubMed]

110. Barteková, M.; Carnická, S.; Pancza, D.; Ondrejcáková, M.; Breier, A.; Ravingerová, T. Acute treatment with polyphenol quercetin improves postischemic recovery of isolated perfused rat hearts after global ischemia. Can. J. Physiol. Pharmacol. 2010, 88, 465-471. [CrossRef]

111. Shoskes, D.; Zeitlin, S.; Shahed, A.; Rajfer, J. Quercetin in men with category III chronic prostatitis: A preliminary prospective, double-blind, placebo-controlled trial. Urology 1999, 54, 960-963. [CrossRef]

112. Li, J.; Xie, C.; Zhuang, J.; Li, H.; Yao, Y.; Shao, C.; Wang, H. Resveratrol attenuates inflammation in the rat heart subjected to ischemia-reperfusion: Role of the TLR4/NF-кB signaling pathway. Mol. Med. Rep. 2015, 11, 1120-1126. [CrossRef]

113. Cheng, L.; Jin, Z.; Zhao, R.; Ren, K.; Deng, C.; Yu, S. Resveratrol attenuates inflammation and oxidative stress induced by myocardial ischemia-reperfusion injury: Role of Nrf2/ARE pathway. Int. J. Clin. Exp. Med. 2015, 8, 10420-10428.

114. Dong, W.; Yang, R.; Yang, J.; Yang, J.; Ding, J.; Wu, H.; Zhang, J. Resveratrol pretreatment protects rat hearts from ischemia/reperfusion injury partly via a NALP3 inflammasome pathway. Int. J. Clin. Exp. Pathol. 2015, 8, 8731-8741.

115. Škemiene, K.; Jablonskiene, G.; Liobikas, J.; Borutaite, V. Protecting the heart against ischemia/reperfusion-induced necrosis and apoptosis: The effect of anthocyanins. Medicina 2013, 49, 84-88. [CrossRef]

116. Nakamura, T.; Goto, M.; Matsumoto, A.; Tanaka, I. Inhibition of NF-kappa B transcriptional activity by alpha-tocopheryl succinate. Biofactors 1998, 7, 21-30. [CrossRef] [PubMed]

117. Lassnigg, A.; Punz, A.; Barker, R.; Keznickl, P.; Manhart, N.; Roth, E.; Hiesmayr, M. Influence of intravenous vitamin E supplementation in cardiac surgery on oxidative stress: A double-blinded, randomized, controlled study. Br. J. Anaesth. 2003, 90, 148-154. [CrossRef]

118. Niki, E. Evidence for beneficial effects of vitamin E. Korean J. Intern. Med. 2015, 30, 571-579. [CrossRef]

119. Miller Iii, E.R.; Pastor-Barriuso, R.; Dalal, D.; Riemersma, R.A.; Appel, L.J.; Guallar, E. Meta-Analysis: High-Dosage Vitamin E Supplementation May Increase All-Cause Mortality Background: Experimental models and observational studies. Ann. Intern. Med. 2005, 142, 37-46. [CrossRef] [PubMed] 
120. Dodd, S.; Dean, O.; Copolov, D.L.; Malhi, G.S.; Berk, M. N-acetylcysteine for antioxidant therapy: Pharmacology and clinical utility. Expert Opin. Biol. Ther. 2008, 8, 1955-1962. [CrossRef] [PubMed]

121. Joshi, D.; Mittal, D.K.; Shrivastava, S.; Shukla, S. Protective role of thiol chelators against dimethylmercury induced toxicity in male rats. Bull. Environ. Contam. Toxicol. 2010, 84, 613-617. [CrossRef] [PubMed]

122. Lu, Y.; Qin, W.; Shen, T.; Dou, L.; Man, Y.; Wang, S.; Xiao, C.; Li, J. The antioxidant N-acetylcysteine promotes atherosclerotic plaque stabilization through suppression of rage, MMPs and NF-кB in ApoE-deficient Mice. J. Atheroscler. Thromb. 2011, 18, 998-1008. [CrossRef]

123. Pasupathy, S.; Tavella, R.; Grover, S.; Raman, B.; Procter, N.E.K.; Du, Y.T.; Mahadavan, G.; Stafford, I.; Heresztyn, T.; Holmes, A.; et al. Early use of $\mathrm{N}$-acetylcysteine with nitrate therapy in patients undergoing primary percutaneous coronary intervention for ST-segment-elevation myocardial infarction reduces myocardial infarct size (the NACIAM trial [N-acetylcysteine in acute myocardial infarction]). Circulation 2017, 136, 894-903. [CrossRef]

124. Rhodes, K.; Braakhuis, A. Performance and Side Effects of Supplementation with N-Acetylcysteine: A Systematic Review and Meta-Analysis. Sport. Med. 2017, 47, 1619-1636. [CrossRef]

125. Tardiolo, G.; Bramanti, P.; Mazzon, E. Overview on the effects of N-acetylcysteine in neurodegenerative diseases. Molecules 2018, 23, 3305. [CrossRef]

126. Riegman, M.; Bradbury, M.S.; Overholtzer, M. Population Dynamics in Cell Death: Mechanisms of Propagation. Trends in Cancer 2019, 5, 558-568. [CrossRef] [PubMed]

127. Tang, L.J.; Luo, X.J.; Tu, H.; Chen, H.; Xiong, X.M.; Li, N.S.; Peng, J. Ferroptosis occurs in phase of reperfusion but not ischemia in rat heart following ischemia or ischemia/reperfusion. Naunyn. Schmiedebergs. Arch. Pharmacol. 2021, 394, 401-410. [CrossRef]

128. Howland, M.A. Risks of parenteral deferoxamine for acute iron poisoning. Clin. Toxicol. 1996, 34, 491-497. [CrossRef] [PubMed]

129. Donfrancesco, A.; Deb, G.; Dominici, C.; Pileggi, D.; Castello, M.A.; Helson, L. Effects of a Single Course of Deferoxamine in Neuroblastoma Patients. Cancer Res. 1990, 50, 4929-4930. [PubMed]

130. Di Lorenzo, C.; Colombo, F.; Biella, S.; Stockley, C.; Restani, P. Polyphenols and Human Health: The Role of Bioavailability. Nutrients 2021, 13, 273. [CrossRef]

131. De Araújo, F.F.; de Paulo Farias, D.; Neri-Numa, I.A.; Pastore, G.M. Polyphenols and their applications: An approach in food chemistry and innovation potential. Food Chem. 2021, 338, 127535. [CrossRef]

132. Ferry, D.R.; Smith, A.; Malkhandi, J.; Fyfe, D.W.; DeTakats, P.G.; Anderson, D.; Baker, J.; Kerr, D.J. Phase I clinical trial of the flavonoid quercetin: Pharmacokinetics and evidence for in vivo tyrosine kinase inhibition. Clin. Cancer Res. 1996, 2, 659-668.

133. Zahedi, M.; Ghiasvand, R.; Feizi, A.; Asgari, G.; Darvish, L. Does Quercetin Improve Cardiovascular Risk factors and Inflammatory Biomarkers in Women with Type 2 Diabetes: A Double-blind Randomized Controlled Clinical Trial. Int. J. Prev. Med. 2013, 4, 777-785.

134. D'Andrea, G. Quercetin: A flavonol with multifaceted therapeutic applications? Fitoterapia 2015, 106, 256-271. [CrossRef]

135. Mendonça, R.; Carvalho, N.; Martin-Moreno, J.; Pimenta, A.; Lopes, A.; Gea, A.; Martinez-Gonzalez, M.; Bes-Rastrollo, M. Total polyphenol intake, polyphenol subtypes and incidence of cardiovascular disease: The SUN cohort study. Nutr. Metab. Cardiovasc. Dis. 2019, 29, 69-78. [CrossRef]

136. Van Jaarsveld, H.; Kuyl, J.; Schulenburg, D.; Wiid, N. Effect of flavonoids on the outcome of myocardial mitochondrial ischemia/reperfusion injury. Res. Commun. Mol. Pathol. Pharmacol. 1996, 95, 65-75.

137. Brosková, Z.; Drábiková, K.; Sotníková, R.; Fialová, S.; Knezl, V. Effect of Plant Polyphenols on Ischemia-Reperfusion Injury of the Isolated rat Heart and Vessels. Phyther. Res. 2013, 27, 1018-1022. [CrossRef]

138. Cebova, M.; Pechanova, O. Protective Effects of Polyphenols against Ischemia/Reperfusion Injury. Molecules 2020, $25,3469$. [CrossRef] [PubMed]

139. Pomerantz, B.; Reznikov, L.; Harken, A.; Dinarello, C. Inhibition of caspase 1 reduces human myocardial ischemic dysfunction via inhibition of IL-18 and IL-1beta. Proc. Natl. Acad. Sci. USA 2001, 98, 2871-2876. [CrossRef] [PubMed]

140. Hung, L.; Chen, J.; Lee, R.; Liang, H.; Su, M. Beneficial effects of astringinin, a resveratrol analogue, on the ischemia and reperfusion damage in rat heart. Free Radic. Biol. Med. 2001, 30, 877-883. [CrossRef]

141. Hung, L.; Chen, J.; Huang, S.; Lee, R.; Su, M. Cardioprotective effect of resveratrol, a natural antioxidant derived from grapes. Cardiovasc. Res. 2000, 47, 549-555. [CrossRef]

142. De Souza, R.F.; De Giovani, W.F. Antioxidant properties of complexes of flavonoids with metal ions. Redox Rep. 2013, 9, 97-104. [CrossRef] [PubMed]

143. Calabrese, E.J.; Mattson, M.P.; Calabrese, V. Resveratrol commonly displays hormesis: Occurrence and biomedical significance. Hum. Exp. Toxicol. 2010, 29, 980-1015. [CrossRef] [PubMed]

144. Shaito, A.; Posadino, A.M.; Younes, N.; Hasan, H.; Halabi, S.; Alhababi, D.; Al-Mohannadi, A.; Abdel-Rahman, W.M.; Eid, A.H.; Nasrallah, G.K.; et al. Potential adverse effects of resveratrol: A literature review. Int. J. Mol. Sci. 2020, 21, 2084. [CrossRef] [PubMed]

145. Hausenloy, D.J.; Garcia-Dorado, D.; Bøtker, H.E.; Davidson, S.M.; Downey, J.; Engel, F.B.; Jennings, R.; Lecour, S.; Leor, J.; Madonna, R.; et al. Novel targets and future strategies for acute cardioprotection: Position Paper of the European Society of Cardiology Working Group on Cellular Biology of the Heart. Cardiovasc. Res. 2017, 113, 564-585. [CrossRef]

146. Verhoef, T.; Morris, S.; Mathur, A.; Singer, M. Potential economic consequences of a cardioprotective agent for patients with myocardial infarction: Modelling study. BMJ Open 2015, 5, e008164. [CrossRef] [PubMed] 
147. Rodrigo, R.; Hasson, D.; Prieto, J.C.; Dussaillant, G.; Ramos, C.; León, L.; Gárate, J.; Valls, N.; Gormaz, J.G. The effectiveness of antioxidant vitamins $\mathrm{C}$ and $\mathrm{E}$ in reducing myocardial infarct size in patients subjected to percutaneous coronary angioplasty (PREVEC Trial): Study protocol for a pilot randomized double-blind controlled trial. Trials 2014, 15, 1-12. [CrossRef] [PubMed]

148. Rodrigo, R.; González-Montero, J.; Sotomayor, C.G. Novel combined antioxidant strategy against hypertension, acute myocardial infarction and postoperative atrial fibrillation. Biomedicines 2021, 9, 620. [CrossRef] [PubMed] 